\title{
Evidence of lacustrine sedimentation in the Upper Permian Bijori Formation, Satpura Gondwana basin: Palaeogeographic and tectonic implications
}

\author{
Tapan Chakraborty* and Soumen SARKaR \\ Geological Studies Unit, Indian Statistical Institute, 203 B.T. Road, Kolkata 700 108, India. \\ *e-mail:tapan@isical.ac.in
}

The Upper Permian Bijori Formation of the Satpura Gondwana basin comprising fine- to coarsegrained sandstone, carbonaceous shale/mudstone and thin coal bands was previously interpreted as the deposits of meandering rivers. The present study documents abundance of wave ripples, hummocky and swaley cross-stratification and combined flow bedforms in the Bijori Formation, suggesting that a significant part of the formation was deposited in a wave-agitated environment. Evidence of near-emergent depositional conditions provided by repeated occurrence of rootlet beds and hydromorphic paleosols, local flooding surfaces denoting rapid fluctuation of water level, occurrences of temnospondyl vertebrate fossils, and absence of tidal signatures and marine fossils suggest a lacustrine rather than marine depositional regime. Five facies associations recognised within the Bijori Formation are inferred to represent fluvial channels and associated floodplains (FA1), lake shorelines (FA2), subaqueous distributary channels and associated levees (FA3), wave- and storm-affected delta front (FA4), and open lacustrine/lower shoreface (FA5) deposits. The planoconcave fluvial channel-fill sandbodies with unidirectional cross-beds are clearly distinguishable from the delta front bars that show a convexo-plan or bi-convex sandbody geometry and dominance of wave and combined flow bedforms. Some of the distributary channels record interaction of fluvial and wave-dominated basinal processes. Major distributary sandbodies show a north to northwest flow direction while wave-affected delta front sandbodies show very complex flow patterns reflecting interaction between fluvial discharge and wave processes. Wave ripple crest trends show that the lake shoreline had an overall east-northeast to west-southwest orientation.

The lack of documented contemporaneous lacustrine or marine sediments in the Satpura Gondwana basin posed a major problem of basin-scale palaeogeographic reconstruction. The existence of Bijori lake solves the problem and the lake is inferred to have acted as repository for the contemporaneous alluvial drainage. Development of the large Bijori lake body implies generation of accommodation space exceeding the rate of sediment supplied and thus represents locus of high tectonic subsidence. Transition of fluvial sediments with red mudstone and calcareous soil profile in the lower part of the succession to carbonaceous shale and coal-bearing lacustrine sediments in the upper part, denote a change from a warm semi-arid climate with seasonal rainfall to a more humid one.

\section{Introduction}

Gondwana sediments of peninsular India have been traditionally considered to be of 'fluvio-lacustrine' origin (Pascoe 1959; Casshyap and Qidwai 1971;
Casshyap 1979; Veevers and Tewari 1995). However, there has hardly been any documentation of the lacustrine facies and sedimentological descriptions mostly deal with fluvial channel-fill and associated floodplain deposits (Casshyap 1979; Raja

Keywords. Satpura basin; Lower Gondwana; facies analysis; combined flow bedforms; hydromorphic soil. 
Rao 1983; Veevers and Tewari 1995). Although there have been a number of reports of possible marine strata (Dutt and Mukhopadhyay 2001; Gupta 1999, 2000) the sedimentological analysis and stratigraphic extent of these deposits has so far remained sketchy. Lack of identification of correlative lacustrine or marine deposits in the bulk of the Gondwana succession poses a major problem for regional palaeogeographic reconstruction. It remains unclear where all these fluvial channels were debouching. This paper reports a study of the Upper Permian Bijori Formation in the eastern part of the Satpura basin (figure 1) and presents a facies analysis of the sediments that clearly records the evidence of wave-induced environment in a large standing body of water. Based on the available data, we argue that this standing body of water represents a fresh water lake rather than an open marine basin. Because lakes are very sensitive to climate and tectonism, in the later part of the paper, we discuss the broader implications of the presence of lacustrine facies in the Bijori Formation.

\section{Geological background}

The Satpura Gondwana basin is the westernmost of several disparate Gondwana sedimentary basins of peninsular India. The sedimentary succession is exposed in an ENE-WSW trending outcrop belt (figure 1) and the basin fill succession attains a cumulative thickness of about $4 \mathrm{~km}$ (Crookshank 1936; Pascoe 1959). The succession is traditionally divided into the lower and upper Gondwana deposits (Crookshank 1936; Pascoe 1959; table 1). The Upper Permian Bijori Formation, a succession of fine- to very coarse-grained sandstone, carbonaceous shale and thin coal beds, forms the uppermost unit of the lower Gondwana succession and is separated by an erosional disconformity surface from the ferruginous sandstone and pebbly sandstone of the overlying Lower Triassic (?) Pachmarhi Formation. The transition of the Bijori Formation to the underlying Motur Formation in the study area is gradational. The age of the Bijori Formation is considered to be early Tatarian (Werneburg and Schneider 1996) based on the presence of temnospondyl amphibians. Tewari (1996) inferred the Bijori Formation to represent meandering stream deposits and reported that the palaeodispersal pattern of the sandstone units is broadly towards the north.

\section{Facies analysis}

We have measured a detailed log of about a kmthick succession of Bijori Formation along the
Jamru Nala (figures 1, 2) that is oriented almost orthogonal to the strike direction of the Bijori outcrops and have examined Bijori facies in the adjacent areas. On the basis of lithology, sedimentary and biogenic structures and nature of the bounding surfaces, the Bijori rocks are subdivided into a number of different facies.

\subsection{Coarse-grained sandstone with unidirectional cross-strata $\left(S_{1}\right)$}

This facies consists of white to yellowish grey, coarse- to very coarse-grained sandstone and the sandstones are characterised by unidirectional trough or planar cross-beds. Cross-beds are 12 to $40 \mathrm{~cm}$ thick and the sandstone bodies made up of facies $\mathrm{S}_{1}$ vary in thickness from $0.30 \mathrm{~m}$ to more than 8 metres. Sandstone bodies usually have a sharp undulating to planar base, a sharp to gradational top overlain by fine-grained lithologies comprising at places fining-upward succession. Volumetrically, this facies forms an important constituent in the lower part of the Bijori Formation (figure 2). Paleocurrent data are unimodal, usually with a strong northerly mode but may show significant variation between exposures with mean direction towards the southwest (figure 2).

\subsubsection{Interpretation}

Coarse grain size and dominantly unidirectional cross-strata indicate that this facies was emplaced by strong unidirectional currents, probably fluvial channels. Locally the present F-U trend is consistent with this interpretation. Variable size of the sandbodies and variable palaeocurrent direction probably reflects different scales of channels and within channel flow variability (Bluck 1974).

\subsection{Fine- to coarse-grained sandstone with different scales of combined flow bedforms $\left(S_{2}\right)$}

Greyish white to grey coloured sandstone of this facies shows extreme variation in grain size with common carbonaceous shale partings and interlayers. Facies units vary in thickness from $20 \mathrm{~cm}$ to more than $160 \mathrm{~cm}$. Rapid lateral variations in grain size and scale of sedimentary structures, abundance of carbonaceous shale partings and intraformational clasts are typical (figure 3). Primary structures present within fine-grained sandstone of this facies include symmetric to asymmetric swaley and hummocky stratification (figure 4), low-angle cross-stratification (figure 5) and low-angle parting lineated parallel lamination. Different scales of symmetric to slightly asymmetric, straight crested 


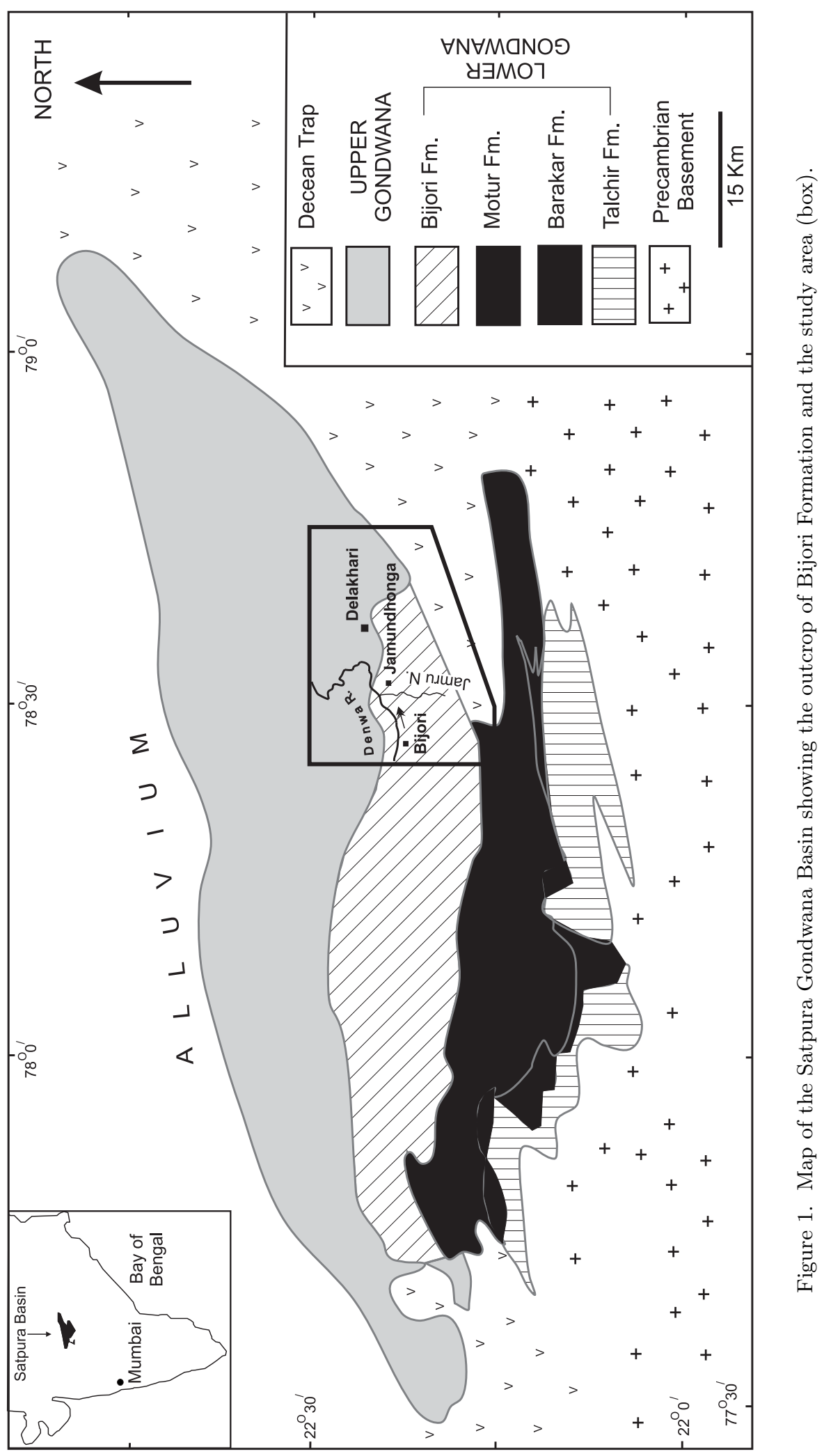


Table 1. The stratigraphic succession of the Satpura Gondwana Basin (modified after Raja Rao 1983; Bandyopadhyay and Sengupta 1999).

\begin{tabular}{|c|c|c|c|}
\hline Formation & Lithology & Thickness & Age \\
\hline \multicolumn{4}{|c|}{ Upper Gondwana } \\
\hline \multirow[t]{2}{*}{ Bagra } & $\begin{array}{l}\text { Conglomerate, pebbly sandstone, red mudstone; } \\
\text { abundant calcareous nodules }\end{array}$ & $\sim 500 \mathrm{~m}$ & Jurassic (?) \\
\hline & Unconformity & & \\
\hline Denwa & $\begin{array}{l}\text { Red mudstone and heterolithic strata alternate } \\
\text { with metre-thick fine to coarse sandstone; caliche } \\
\text { profiles common }\end{array}$ & $300-450 \mathrm{~m}$ & Anisian \\
\hline \multirow[t]{2}{*}{ Pachmarhi } & $\begin{array}{l}\text { Very coarse pebbly sandstone with minor grey/red } \\
\text { mudstone. Multi-storeyed sandstone with large } \\
\text { compound bedforms }\end{array}$ & $500-800 \mathrm{~m}$ & Lower Triassic \\
\hline & $\longrightarrow$ Unconformity & & \\
\hline \multicolumn{4}{|c|}{ Lower Gondwana } \\
\hline Bijori & $\begin{array}{l}\text { Fine to very coarse sandstone alternate with } \\
\text { carbonaceous shale and thin coal beds. Abun- } \\
\text { dant plant impressions, roots and wave-generated } \\
\text { structures }\end{array}$ & $800-1000 \mathrm{~m}$ & $\begin{array}{l}\text { Upper Permian } \\
\text { (Kazanian-Tatarian) }\end{array}$ \\
\hline Motur & $\begin{array}{l}\text { Thick red mudstone-dominated succession with } \\
\text { embedded lenses and sheets of medium- to very } \\
\text { coarse sandstone; mudstone may be white, green } \\
\text { or purple or dark grey; silicified wood fossils com- } \\
\text { mon. Sandstone to mudstone ratio varies from } \\
\text { 1:10 to } 3: 1 \text {. Cross-beds abundant in sandstone; } \\
\text { calcareous nodules of pedogenic origin typify red } \\
\text { mudstone }\end{array}$ & $330-480 \mathrm{~m}$ & $\begin{array}{l}\text { Lower Permian } \\
\text { (Ufimian-Kazanian) }\end{array}$ \\
\hline Barakar & $\begin{array}{l}\text { Quartzo-feldspathic, medium to very coarse sand- } \\
\text { stone. Sandstone white to yellowish orange; three } \\
\text { major coal seams and associated carbonaceous } \\
\text { shales interbedded with sandstone in the upper } \\
\text { part of the formation. Contact with Motur Fm. } \\
\text { sharp to gradational. Decimetre-scale cross-beds } \\
\text { typical of sandstone; wave ripple and parallel lam- } \\
\text { ination common in coal-shale units }\end{array}$ & $140-225 \mathrm{~m}$ & $\begin{array}{l}\text { Lower Permian } \\
\text { (Artinskian) }\end{array}$ \\
\hline \multirow[t]{3}{*}{ Talchir } & $\begin{array}{l}\text { Boulder-pebble conglomerate, pebbly sandstone } \\
\text { and khaki green shale }\end{array}$ & $100-250 \mathrm{~m}$ & $\begin{array}{l}\text { Upper } \\
\text { Carboniferous (?) }\end{array}$ \\
\hline & $\longrightarrow$ Unconformity & & \\
\hline & Gneisses, quartzites, granites, etc. & \multicolumn{2}{|c|}{ Precambrian } \\
\hline
\end{tabular}

to slightly sinuous crested ripples are also common (figure 6). The low-angle stratification of this facies apparently resembles trough cross-stratification, but their distinctive features include finer grain size, much gentler dipping foresets (less than angle of repose), lateral change of the foresets to subhorizontal strata (figures 4,7), draping and overshooting of the foresets, bundled upbuilding of packages of strata (figure 5) and abundance of mudstonedrapes and mudstone-clasts (figure 3). The lowangle cross-stratification are always associated with wave ripple lamination or swaley/hummocky stratification and show variable foreset dip directions. Hummocky or swaley features typically have wavelengths varying from $50-150 \mathrm{~cm}$ but can be in rare instances up to $700 \mathrm{~cm}$. Amplitudes vary between 15 and $50 \mathrm{~cm}$. Low-angle truncation between stratal packages, and mudstone-clasts are commonly associated with the swales or hummocks. Coarse-grained sandstone units of the facies are usually characterized by trough or planar crossbedding with angle-of-repose foresets.

\subsubsection{Interpretation}

The presence of hummocky and swaley strata indicates deposition of this facies under the action of long-period wave-agitated environment (Harms et al 1982; Arnott and Southard 1990; Southard et al 1990). Symmetric straight crested ripples with tuning fork like bifurcation corroborate wave action in the depositional environment. Slightly 

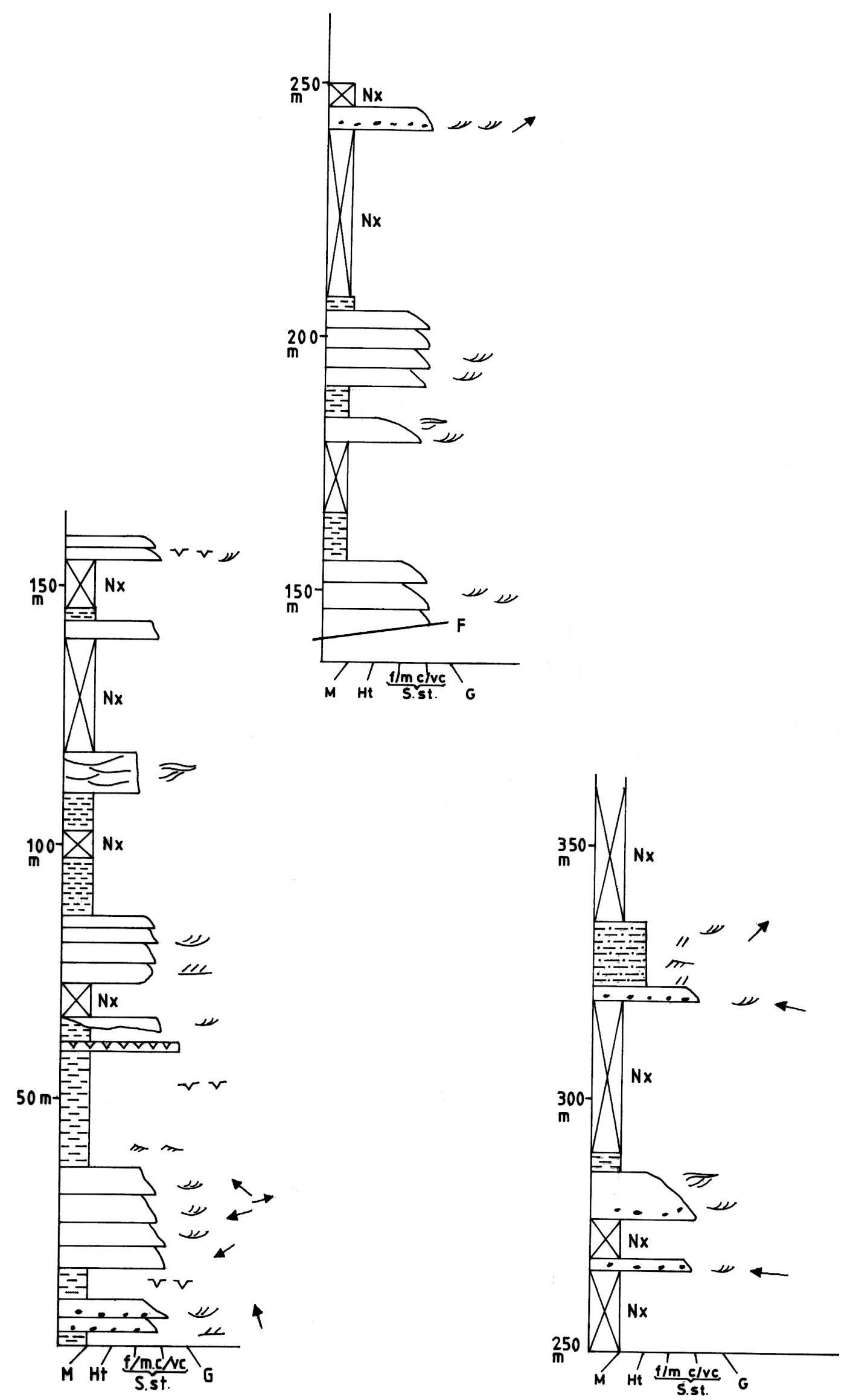

Figure 2. Generalized log of the entire succession of Bijori Formation along the Jamru Nala section. 

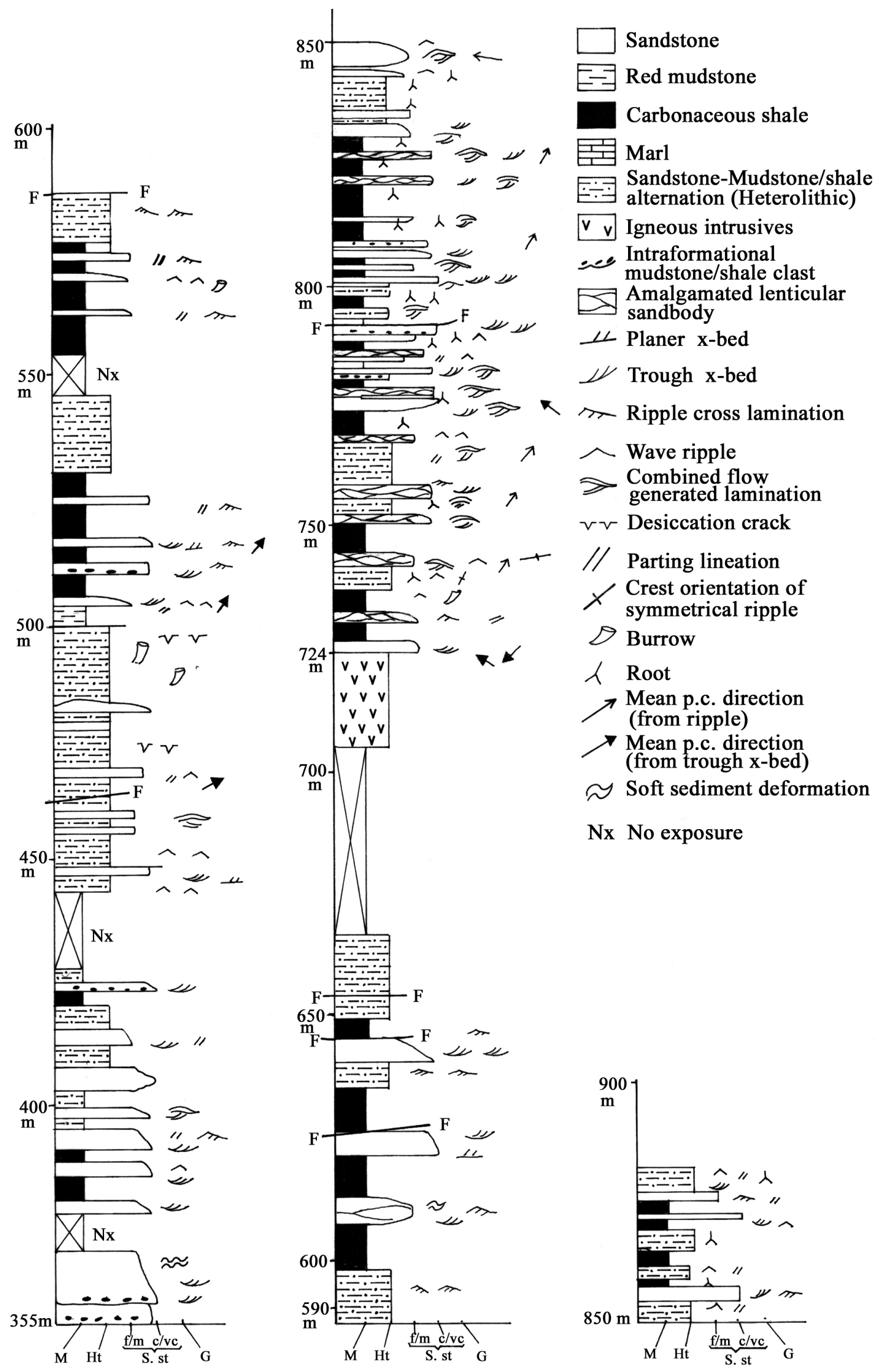

Figure 2. (Continued) 


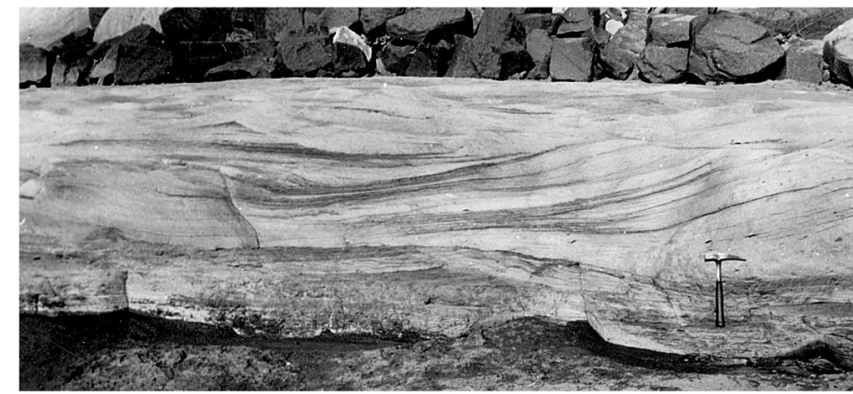

Figure 3. Abundant shale drapes and clasts within coarse to fine-grained combined flow dune stratified sandstone. Jamru Nala section one km SSW of Janundhonga village.

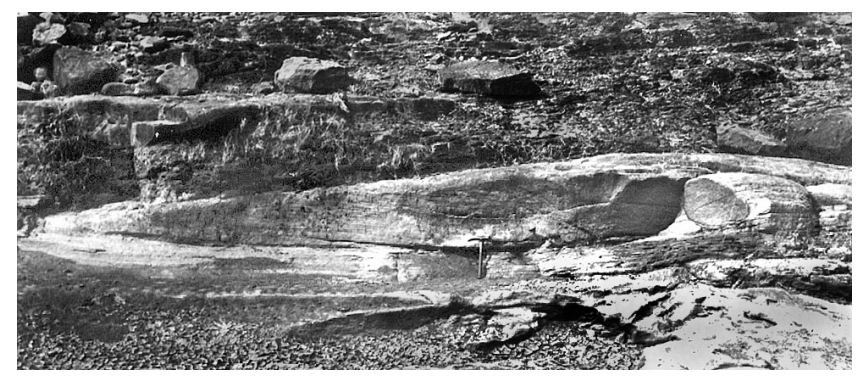

Figure 4. Symmetrically filled low-amplitude swale. Note that the infilling laminae are concordant with the lower bounding surface of the swale. Denwa river section.

asymmetric straight crested ripples of this facies are inferred to be the product of combined unidirectional and oscillating current (Harms 1969).

Wave tank experiments indicate that at an intermediate energy condition in a combined flow environment between upper stage plane bed and small ripples, large, asymmetric combined flow 3-D dunes develop with internal features closely resembling large-scale trough cross-stratification (Arnott and Southard 1990; Myrow and Southard 1991). But the foresets of these trough cross-strata have inclination less than that of angle of repose. Lowangle trough-like cross-stratifications have been reported from both modern and ancient shallow marine and lacustrine deposits and are believed to have been affected by combined flow regime (Nottvedt and Kreisa 1987; Buatois and Mangano 1995a, b; Van de Meene et al 1996; Datta et al 1999). It has been documented from the ancient shallow marine environment that there exists a continuum of structure between symmetrical hummocks/swales to asymmetric low-angle cross-strata (Surlyk and Noe-Nygaard 1986; Datta et al 1999) depending upon the relative strength of the unidirectional and oscillatory flow component as well as grain size. We infer a similar wave-current agitated environment for facies $\mathrm{S}_{2}$. It is worth emphasising here that hummocky bedforms and 3-D combined

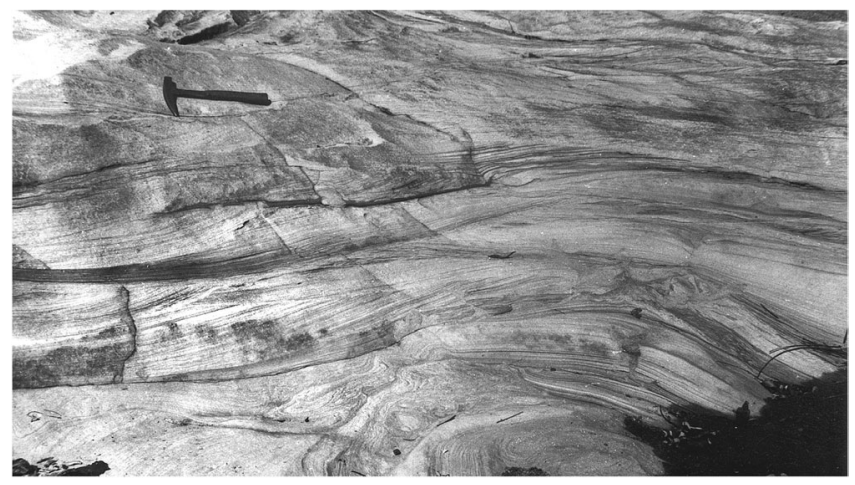

Figure 5. Details of the combined flow 3-D dune showing change of low-angle foresets to sub-horizontal strata, low-angle discordances between stratal packages, bundled upbuilding of reverse dipping strata set. Jamru Nala near Jamundhonga village.

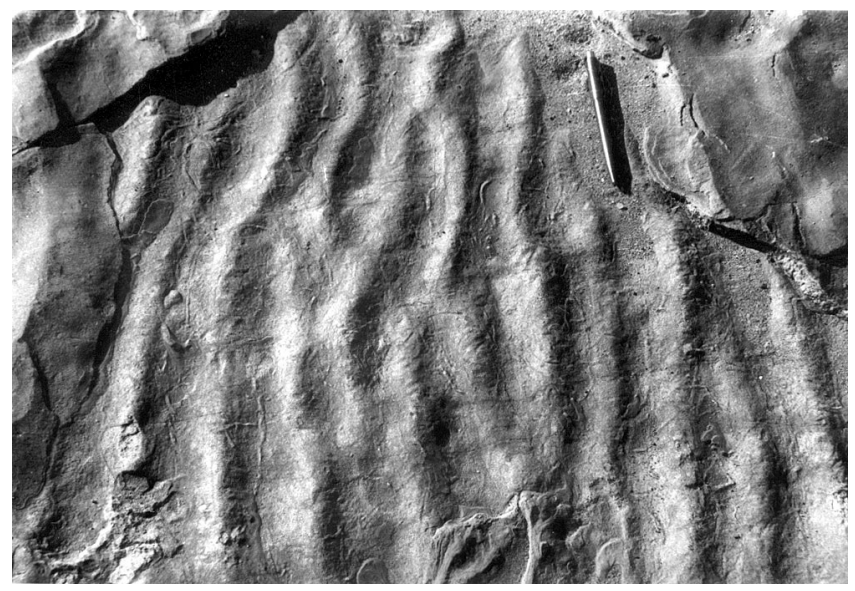

Figure 6. Slightly sinuous symmetric wave ripples in the facies $\mathrm{S}_{2}$ of the Bijori Formation. Note tuning fork like bifurcation of the crestlines and possible trail marks on the rippled surface. A 14-cm pen for scale.

flow dunes are not unique to shallow marine depositional realm but is now known to be well-developed in lacustrine setting (Duke 1985; Eyles and Clark 1986, 1988; Greenwood and Sherman 1986; Hamblin 1992; Dam and Surlyk 1993; Buatois and Mangano 1995b).

\subsection{Ripple-laminated, sparsely burrowed fine-grained sandstone $\left(S_{3}\right)$}

The facies comprises fine- to medium-grained muddy sandstone with small-scale ripples as the dominant sedimentary structure. Facies units range in thickness from 20 to $60 \mathrm{~cm}$. The ripples show gentle foresets with locally developed silty partings. Rib and furrow structures exposed on bedding planes record variable flow directions. Ripple foresets have less than angle-of-repose dip and 


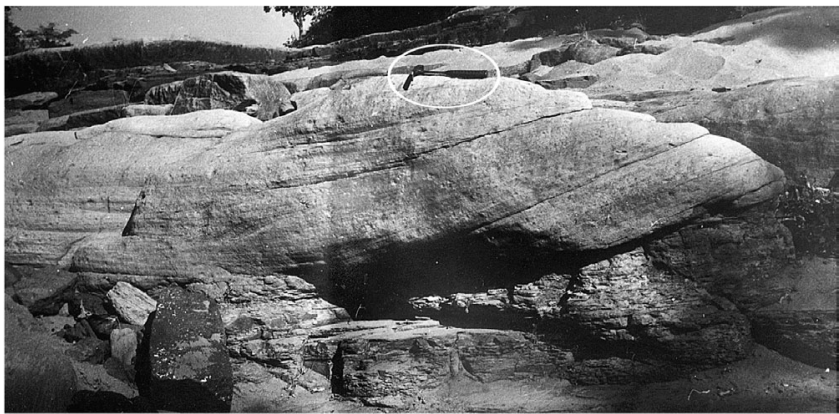

Figure 7. Large scale combined flow bedform in the Jamru Nala section. Note its geometry intermediate between large trough cross-strata and swaley cross-strata and transition of dipping foresets to subhorizontal strata.

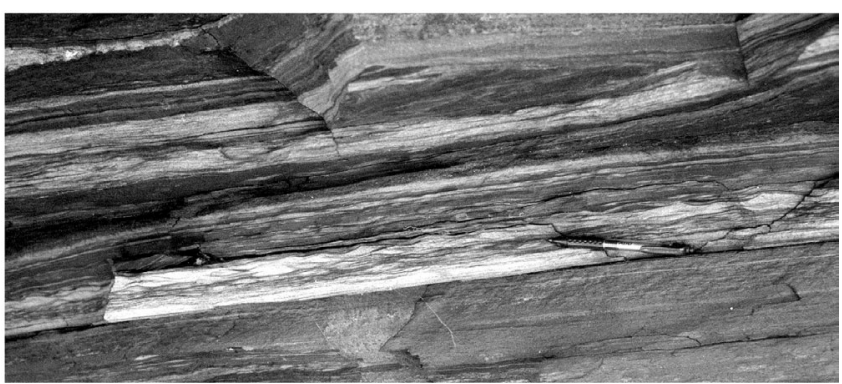

Figure 8. Heterolithic stratification of facies Ht. Note variable proportion of sand and mud, and also wave ripple stratification within fine sandstone units.

at places show bundled upbuilding pattern, and the top of the beds are commonly marked by slightly asymmetric straight crested ripples. In some of the exposures, top of the sandbodies show traces of grazing organism with well-preserved meniscate structure and lining.

\subsubsection{Interpretation}

Finer grain size and smaller size of bedforms in this facies (as compared to $S_{1}$ or some of the $S_{2}$ units) indicate deposition in comparatively low-energy environments. Gentler dips of the foreset laminae and straight, bifurcating crest lines of ripples indicate that these are combined flow ripples (Harms 1969). The inferred depositional environment was characterized by high input of fine-grained sediments, low-energy combined wave and current agitation. Such facies are common in many subaqueous environments, particularly at the mouth of rivers in lakes or marine basins where unidirectional fluvial plumes during flood supply the fine sediments, whereas superimposed wave agitation represent the basinal processes (Elliot 1976a, b; Brettle et al 2002). During non-flood times the tops of these fluvial plumes deposited bodies were colonised by burrowing organisms.

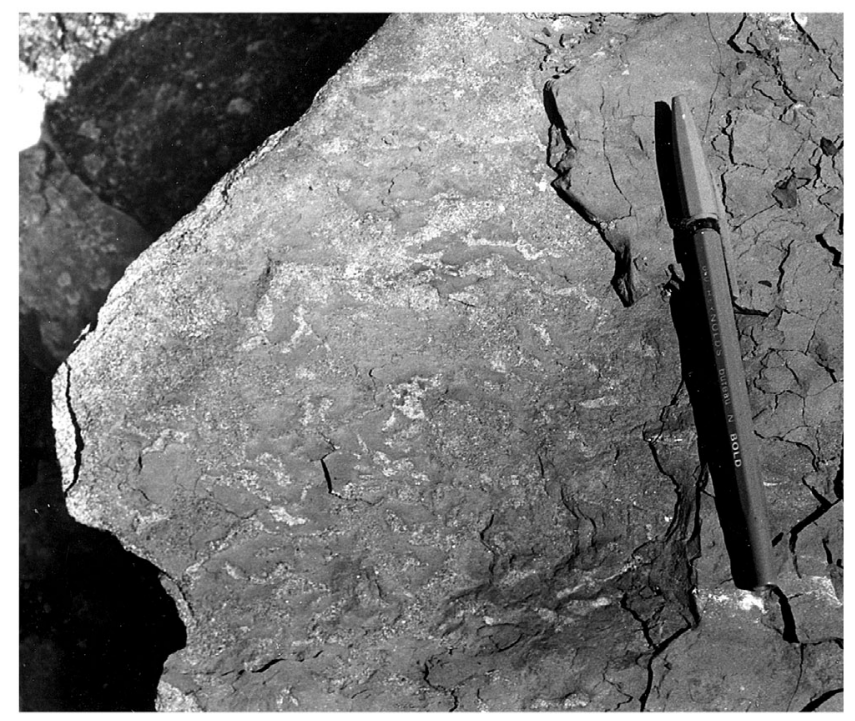

Figure 9. Linear, irregular shrinkage cracks (synaeresis) in Heterolithic (Ht) facies.

\subsection{Heterolithic facies (Ht)}

A varying range of fine scale sandstone-mudstone alternations characterises the facies. The sandstone is fine- to medium-grained and varies in thickness from a few $\mathrm{mm}$ to $30 \mathrm{~cm}$, and alternate with grey or dark carbonaceous shale of variable thickness (figure 8). The siltstone and fine sandstone strata in the heterolithic units are characterized by a variety of sedimentary structures including parallel lamination, small lenticular beds and wave ripple laminations of different scales. The grey shales or carbonaceous mudstones are usually characterized by parallel laminations. Cracks of varying dimensions commonly with silty fills are encountered at places. The cracks, in contrast to the polygonal geometry of desiccation features, have a highly irregular geometry (figure 9).

\subsubsection{Interpretation}

The alternation of laminated carbonaceous shale/ mudstone and fine-grained sandstone-siltstone layers indicate either a deep-water environment below fair-weather wave base or a shallow quiet water environment protected from intense wave agitation and abundant coarse clastic input. Irregular pattern of the cracks and isolated nature of their occurrences in this facies probably suggest a subaqueous origin of the cracks (Plummer and Gostin 1981; Collinson and Thompson 1989). The presence of laminated mudstone, absence of emergence features and close association with $\mathrm{M}_{3}$ mudstone (see table 2) indicate that this facies was probably deposited in deeper water. Wave-rippled siltstone or fine-grained sandstone interlayers indicate periodic influx of coarser sediment within the quiet 


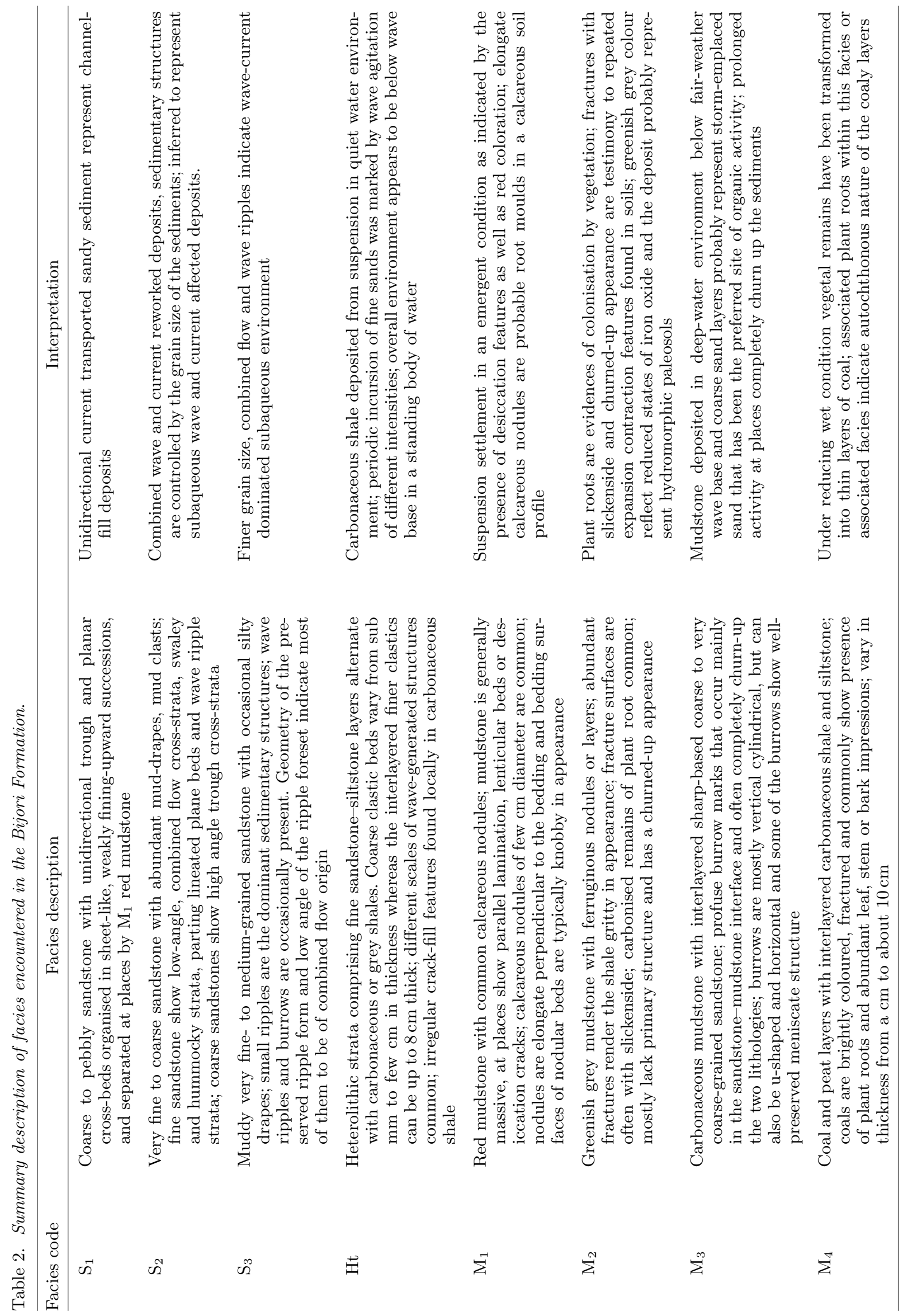




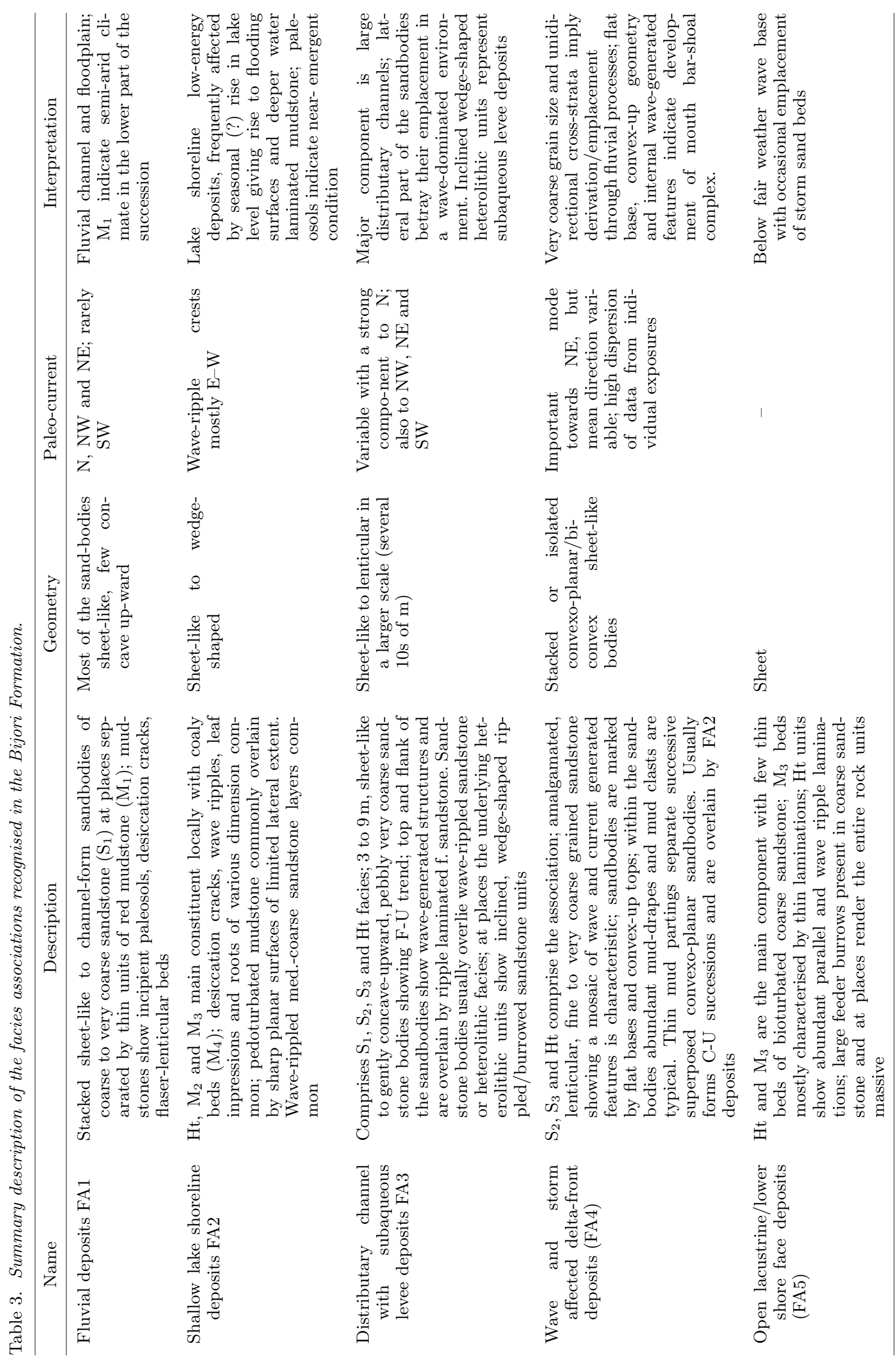




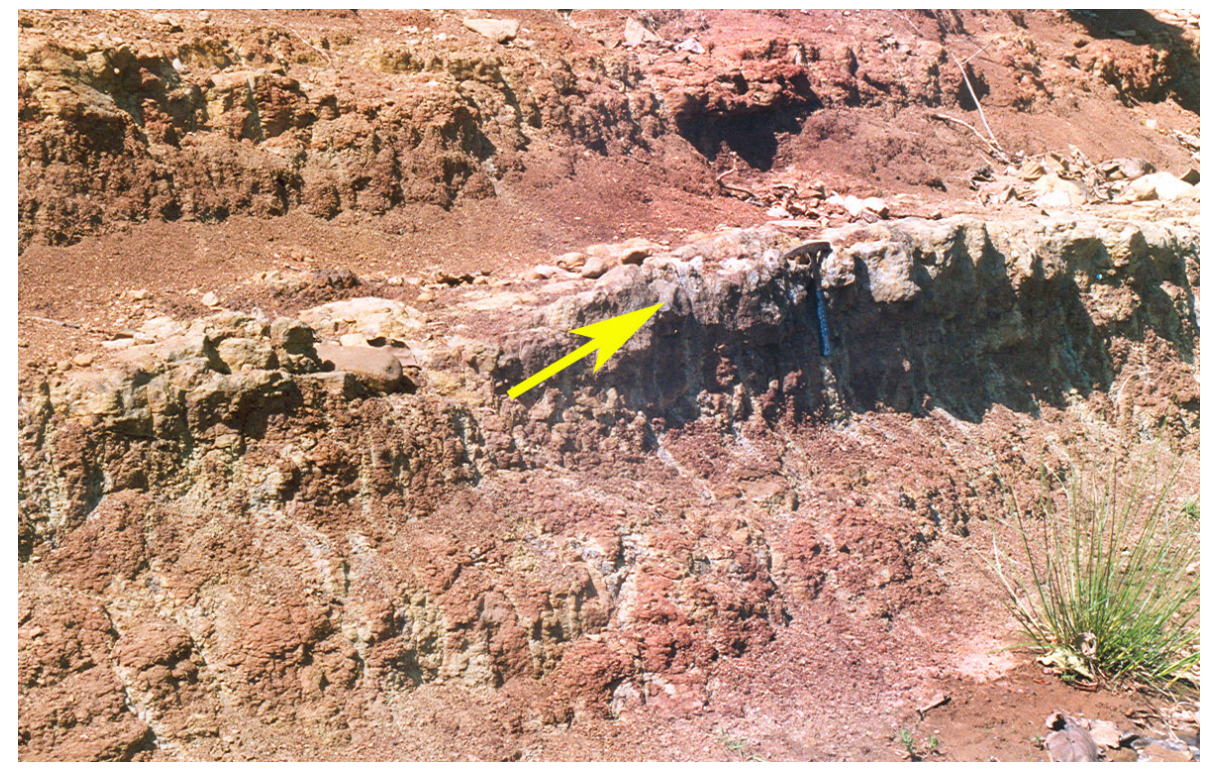

Figure 10. Caliche profile within red mudstone of $\mathrm{M}_{1}$. Note development of vertically oriented cylindrical carbonate nodules (arrow) in the thin sandstone bed above and an interconnected network of calcium carbonate in the mudstone below.

water environment, and generation of wave ripples or parallel lamination within them are assigned to the action of storms. The dark colour of the shales suggest a poorly-oxygenated bottom environment and the deposition is inferred to have taken place in a deeper water environment below fair-weather wave base that was periodically churned by storm waves.

\subsection{Red mudstone with calcareous nodules $\left(M_{1}\right)$}

This facies occurs as units of red mudstone tens of $\mathrm{cm}$ to $150 \mathrm{~cm}$ thick and the facies is restricted to the lower part of the Bijori Formation. Thin layers of ripple laminated fine-grained sandstone and desiccation cracks have been noted in some exposures. Calcareous nodules are common and at places impart a knobby look to the bedding plane exposures of the mudstone units. Calcareous nodules are usually elongate perpendicular to bedding (figure 10), they are a few cms across and up to $10 \mathrm{~cm}$ long. Horizontal laminations are at places visible in the mudstone where the calcareous nodules are absent. Thin section study reveals pervasive early diagenetic carbonate cement.

\subsubsection{Interpretation}

The red colouration, desiccation cracks and small ripples indicate deposition of the mudstone in shallow, well-oxygenated water close to the water-air interface. Pervasive carbonate cement and nodular concretions are inferred to indicate development of calcareous paleosol during subaerial exposure for a rather prolonged period in a hot, semi-arid climate.
Occurrence of the mudstone interlayered between facies $\mathrm{S}_{1}$ sandstone units probably implies a floodplain origin (cf. Collinson 1996).

\subsection{Greenish grey, bioturbated massive carbonaceous shale $\left(M_{2}\right)$}

The facies has a typical dark greenish grey colour and a fractured, massive appearance and varies in thickness between several $\mathrm{cm}$ to more than $80 \mathrm{~cm}$. Slickensided surfaces are common (figure 11) and the facies lacks any regular stratification. Isolated pockets of coarse sandstone are encountered at places. One of the major features is the occurrence of different types of plant roots identified by vertical to sub-vertical, carbonised, cylindrical, straight to sinuous bodies that show a downward branching pattern (figure 12). Diameter of the roots varies from less than a $\mathrm{mm}$ to several $\mathrm{mm}$. Roots disrupt original bedding laminae. At places abundant plant remains and large stem impressions characterise the bedding plane exposures (figure 13). Welldeveloped desiccation cracks occur at places. The facies units generally have a gradational lower contact with the underlying sandstone or heterolithic facies, whereas the upper contact is sharp. Commonly the facies unit is overlain across a sharp planar boundary by a heterolithic unit that shows well-developed lamination, and traces of roots are truncated below this surface.

\subsubsection{Interpretation}

The fine grain size indicates low energy environment and plant roots indicate growth of abundant vegetation. Abundant fractures in $\mathrm{M}_{2}$ mudstone 


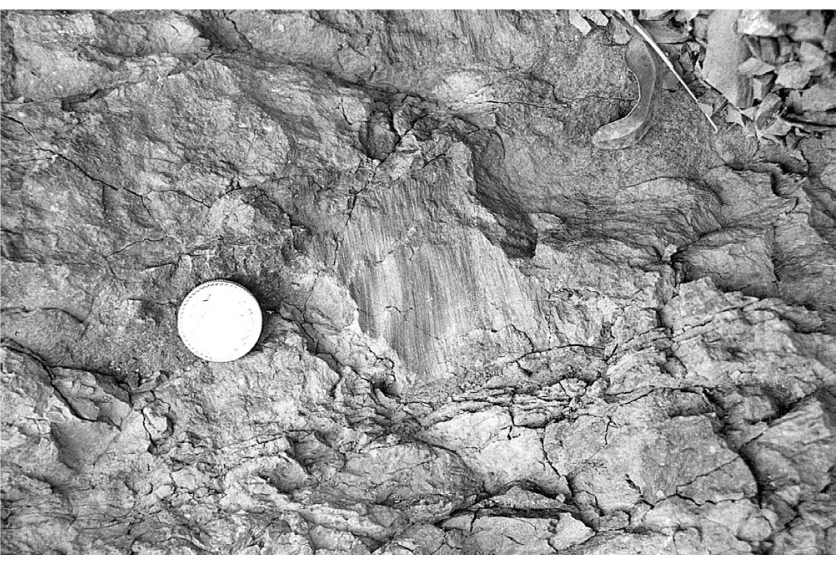

Figure 11. Common slickensided surfaces within hydromorphic paleosol $\left(\mathrm{M}_{2}\right.$ facies $)$. The mudstone has a massive fractured appearance.

probably represent soil peds and slickensided surfaces are reportedly common in the soil profiles and form in response to shrink-swell processes operative within these zones (Retallack 1997). Churned-up appearance, abundant fractures with slickensides, roots and greenish grey colour of the mudstone indicate development of hydromorphic paleosol profile that are typical of perennially water-logged, vegetated mudflats (Duchaufour 1982; Besley and Fielding 1989). Presence of carbonised remains of roots supports the above interpretation. Greenish grey colour of the mudstone indicates an oxygenpoor environment and ferrous state of the iron in the paleosol profile.

\subsection{Carbonaceous mudstone with interlayers of burrowed coarse-gained sandstone $\left(M_{3}\right)$}

This facies also comprises mudstone with interlayers of coarse- to very coarse-grained sandstone. The carbonaceous mudstone is thinly laminated. At places, particularly where the coarse sandstone interlayers occur, this facies is characterised by massive and churned-up appearance where large flakes of micas are found to be oriented randomly. Instead of carbonised root remains, this facies is characterised by various types of feeding burrows. The burrowing organisms usually colonised the sandstone-mudstone interface (figure 14) rendering either the sandstone or both the sandstone and the mudstone structureless. The facies is commonly interlayered between heterolithic units that show various types of wave-generated features. Roots are conspicuous by their absence in this facies.

The burrows vary in diameter from a few $\mathrm{mm}$ to $18 \mathrm{~mm}$. The burrows may be vertical, horizontal or u-shaped, and the burrow-filling may comprise massive coarse-grained sandstone or finer-grained muddy sandstone; meniscate structures are well developed at places.

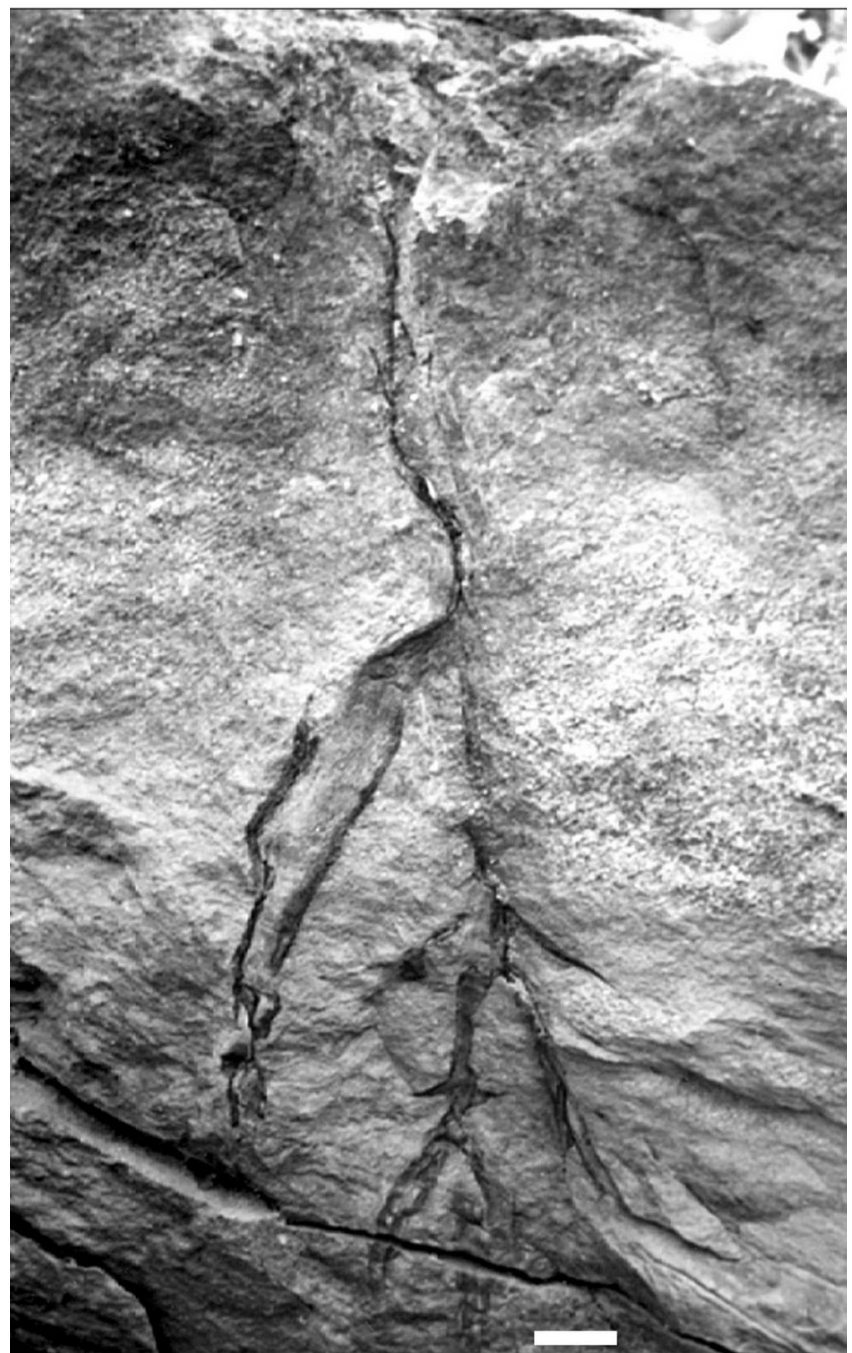

Figure 12. Typical appearance of carbonised plant roots within Bijori mudstone-sandstone alternations. The subvertical root structure penetrates a number of layers and shows a downward branching pattern. Scale bar is $4.5 \mathrm{~cm}$.

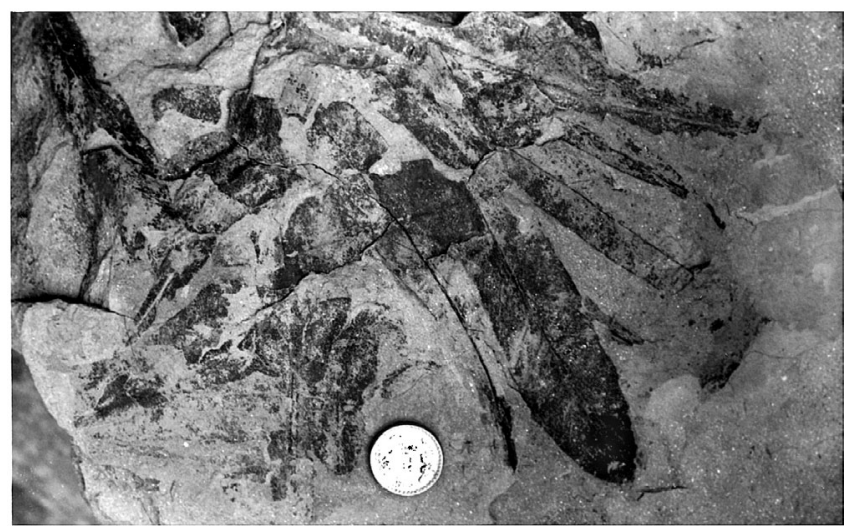

Figure 13. Plant impressions in the facies $\mathrm{M}_{2}$.

\subsubsection{Interpretation}

Common interlayering of the facies with heterolithic units (Ht) and complete churning of the 


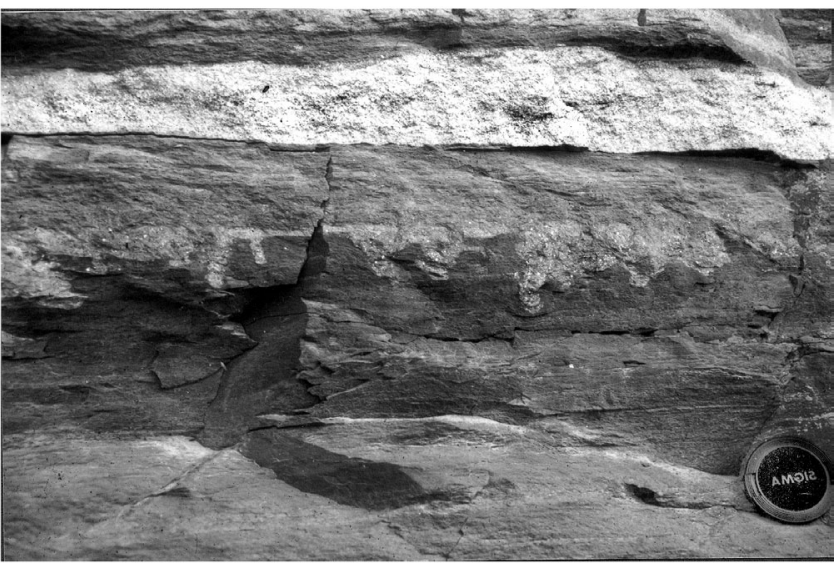

Figure 14. Intensely burrowed sandstone within the deepwater mudstone of facies $\mathrm{M}_{3}$.

sediments by burrowing organisms are indicative of low-rate of sedimentation in a quiet-water environment. The coarse-grained, bioturbated sandstone beds probably represent infrequent incursion of storms into deeper water environment that was otherwise characterised by suspension settlement of fine mud. The storm-emplaced sand beds within surrounding deep-water mud were supplied with required nutrients and oxygen. Therefore, these horizons became the initial site for burrowing activity. Prolonged organic activity resulted in complete destruction of the primary structure and generation of a random fabric of the grains. The deeper water interpretation for this facies unit is further supported by the absence of roots and desiccation features common in many carbonaceous shale units of Bijori Formation.

\subsection{Peat and coal $\left(M_{4}\right)$}

Carbonaceous shales of facies $\mathrm{Ht}$ or $\mathrm{M}_{2}$ are at places interlayered with thin peat/coal layers. These layers vary in thickness from $1.5 \mathrm{~cm}$ to about $25 \mathrm{~cm}$ and comprise bright coal layers with vertical layer-perpendicular fractures. The associated carbonaceous shales show abundant plant impressions, roots or hydromorphic soil horizons. The common leaf impressions include Glossopteris sp., Gangamopteris sp., Taeniopteris sp., Schizoneura $s p$., Vertebraria stem and impressions of different other types of stems or barks are also common. Fragments of coals are common in many overlying sandstone beds, particularly near the base of the sandstone units.

\subsubsection{Interpretation}

Coaly layers formed from the accumulations of vegetal remains in a waterlogged anoxic environment (Duchaufour 1982). These layers evidently formed in coal marshes and probably indicate a waterlogged near-emergent condition where large amount of vegetal debris accumulated. Associated root beds indicate much of the vegetal remains are autochthonous in nature. Peat is indicative of wet climatic condition with rainfall distributed throughout the year.

\section{Lacustrine origin of the Bijori Formation}

The facies of the Bijori Formation indicate interplay of current and wave-generated sedimentation processes. Evidence of fluvial regime is borne out by facies $S_{1}$ and $M_{1}$ and the succession bears evidences of interaction of the fluvial- and wavedominated basinal processes in a marine or a lacustrine basin. In many cases distinction between these two environments are difficult on the basis of physical sedimentary structures alone (Talbot and Allen 1996; Buatois and Mangano 1995a). A lacustrine origin is, however, suggested for a large part of the Bijori Formation based on the following reasons.

1. One of the major distinctions between the marine and lacustrine processes is the presence of tidal currents in the former, whereas it is either absent or very weak in the lakes. Heterolithic units and mud-flasers are common in the Bijori Formation but periodic tidal bundles, tidal rhythmites or palaeocurrent reversals in the adjacent cross-beds (herringbone cross stratification) have not been found. Therefore, the sandstone-mudstone alternations commonly present in the Bijori Formation are inferred to represent fluctuating energy condition in wave-current depositional regime that can very well form in a lake shoreline (cf., Dam et al 1995; Buatois and Mangano $1995 \mathrm{a}, \mathrm{b})$.

2. The formation is gradationally underlain by the fluvial Motur Formation (Ray and Chakraborty 2002) and is overlain across a disconformity by braided fluvial deposits of Pachmarhi Formation (Maulik et al 2000). This is not a diagnostic criterion, but the paucity of reported marine deposits above the Barakar Formation in different Gondwana basins of peninsular India (Veevers and Tewari 1995) and the presence of alluvial deposits in the encasing units of the Bijori Formation are indicative of a continental affinity.

3. Similar wave- and current-dominated facies can form in both lacustrine and shallow marine environment. Beside geochemical analyses fossils provide one of the major clues for 
discrimination between a fresh water and a marine or brackish water wave-influenced environment (cf., Buatois and Mangano 1995a; Dam and Surlyk 1993). No fossils of marine affinity have so far been reported from the Bijori Formation; on the other hand, a temnospondyl amphibian Gondwanosauras bijoriensis has been reported from this horizon (Lydekker 1885; Crookshank 1936). Independent palaeoecological interpretation based on Gondwanosauras is difficult because of its poor preservation (Bandyopadhyay 1999). Fossil amphibians are known from both fluvial and brackish water environment (Schoch and Milner 2000). Gondwanosauras bijoriensis has been tentatively assigned to the rhinesuchids (Werneburg and Schneider 1996). Rhynesuchids have been discovered from the Karoo Supergroup of South Africa (Schoch and Milner 2000). The Rhynesuchid bearing horizon of the Karoo has been inferred as fluvial floodplain successions (Smith 1993). The presence of similar vertebrate faunas and the absence of marine fossils support a fresh water lacustrine environment for Bijori Formation.

4. Root or in situ plant traces are common throughout the $\mathrm{km}$ thick succession of the Bijori Formation (figures 12, 13). Even the swaley cross-stratified sandstone of facies $\mathrm{S}_{2}$ is at places found to contain large stem impressions indicating that even the storm affected sands periodically became emergent, a situation unlikely to be met repeatedly in an open marine condition. Peat mires and abundant plant growth, however, is a common feature in many barred coastal marine successions (Nemec 1992) or marine deltaic coastlines (Elliot 1976a; Buillit et al 2002). However, evidences of roots almost at every five metres of the Bijori succession (figure 15) probably denote repeated, rapid fluctuation of the water level, and appears to be more consistent with a lacustrine environment; this environment is known to rapidly respond to even shortterm seasonal hydrological changes (Talbot and Allen 1996).

5. At many places the rooted mudstone succession is separated across a sharp boundary from the overlying thinly laminated or wave-rippled heterolithic units completely devoid of root traces or associated paleosol features. We infer these bounding surfaces to represent flooding surface denoting rapid rise of water level. Such surfaces are common in the Bijori succession and individual flooding surfaces cannot be traced for more than few hundreds of metres and are, therefore, inferred to represent local water level fluctuations that are distinct from the major marine flooding surfaces. Major marine flooding surfaces are regionally extensive and off set the facies belts. Local water level fluctuations are very common in lacustrine successions where seasonally the water level may change rapidly and the lake shoreline can migrate several kilometres (Talbot and Allen 1996). Frequency of occurrences of these flooding surfaces and associated features discount a tidal origin of these features.

The overall environment of the Bijori Formation is therefore inferred as a lake delta and the characteristics of different depositional sub-environments are described below as different facies associations. The geochemical analyses and palynological studies (cf. Dam and Surlyk 1993; Dam et al 1995) should, however, provide confirmatory evidences for lacustrine interpretation.

\section{Facies associations}

In the Bijori succession, combination of different facies and a characteristic geometry of the constituent lithosome define six different facies associations. Each of these associations can be inferred in terms of a distinct subenvironment within the lacustrine depositional system.

\subsection{Fluvial facies association (FA1)}

This association consists of $\mathrm{S}_{1}, \mathrm{Ht}$ and $\mathrm{M}_{1} . \mathrm{S}_{1}$ sandstone bodies are stacked and grade upward into $\mathrm{M}_{1}$ mudstone with desiccation cracks and calcareous nodules. Heterolithic units (Ht) are interlayered at places. The $\mathrm{S}_{1}$-dominated sandbodies are commonly stacked across planar contacts and less commonly show pronounced concave-up geometry, particularly where they overlie $\mathrm{M}_{2}$ red mudstone. This facies association is particularly common in the lowest part of the studied succession (figure 2). Sandstone bodies vary in thickness from 150 to $375 \mathrm{~cm}$ but may be $>9 \mathrm{~m}$ thick and $\mathrm{M}_{2}$ red mudstones are usually $30-50 \mathrm{~cm}$ thick but, in places, can be up to $8 \mathrm{~m}$ thick.

\subsubsection{Interpretation}

The facies association is interpreted as fluvial deposits. Thick cross-stratified sandstone bodies represent the channel-fill units, whereas the red mudstones with calcareous paleosols represent deposition in the alluvial flood plain (Chakraborty et al 2000). The floodplain facies show that the floodplain sediments were subaerially exposed under a semi-arid condition. The sheet-like geometry of the $\mathrm{S}_{1}$ sandstone bodies, their multi-storied 
nature and coarse grain size, relatively low proportion of mudstone, absence of lateral accretion surfaces and low dispersion of the palaeocurrent data probably imply a low sinuosity sandy channel system.

\subsection{Shallow lake shoreline facies association (FA2)}

This facies association comprises the $\mathrm{Ht}, \mathrm{M}_{2}, \mathrm{M}_{3}$, $\mathrm{S}_{2}$ and $\mathrm{M}_{4}$ facies. The greenish grey mudstone with abundant roots (figure 12) is a major component and in many cases is separated from heterolithic carbonaceous shale by a sharp erosional surface. The facies association shows remarkable lateral facies variation and individual facies may pinch out within 100 metres. This facies association usually shows a coarsening upward trend but in many exposures a well-defined trend is lacking.

\subsubsection{Interpretation}

The association represents an environment that was affected by wave-agitated shallow water and suffered periodic emergence and plant colonisation. Many of the present day lake coasts are characterised by swamps (Talbot and Allen 1996) implying broad similarity of the facies association with that of many modern lake shoreline deposits. Commonly occurring sharp surfaces that terminate root beds are inferred to represent seasonal lacustrine flooding surfaces. Lake shorelines are known for their susceptibility to seasonal flooding, during which the shoreline can migrate several kilometers landward drowning areas previously exposed or covered by shallow water (Talbot and Allen 1996). Repetitive occurrences of these flooding surfaces in the succession (figure 15), emergent or nearemergent, vegetated nature of the depositional site, the limited lateral extent of the individual facies lithosomes, lack of evidences for significant change in the water depth or major shift in facies tract discount origin of these strata through marine flooding and appears to be consistent with lake shoreline environment.

\subsection{Subaqueous distributary channel facies association (FA3)}

The facies association comprises the $\mathrm{S}_{1}, \mathrm{~S}_{2}, \mathrm{~S}_{3}$ and $\mathrm{Ht}$ facies and forms fining-upward successions. It usually overlies wave-rippled $\mathrm{M}_{3}$ or $\mathrm{Ht}$ facies with an erosional base. The lower part of most of the sandstone bodies comprises very coarse-grained trough cross-bedded sandstone and upward both the scale of the cross-beds and the grain size decrease rapidly. In an exceptionally good exposure at the Denwa River, a FA3 sandbody can be traced transverse to palaeoflow direction for several hundred metres. The coarsegrained, erosively-based sandstone body becomes thinner laterally and grades into a fine-gained sandstone with wave ripple lamination, combined flow dune cross-stratification and hummocky and swaley stratification (figure 4). The sandstonedominated facies is usually overlain by heterolithic sandstone-carbonaceous shale alternations.

In some of the exposures the metre-scale sandstone bodies erosively overlie a succession of finegrained sandstone-carbonaceous shale alternations (figure 16). In the sandstone-carbonaceous shale succession each of the sandstone beds is several tens of $\mathrm{cm}$ thick, sharply based and grades upward into carbonaceous shale. Individual sandstone beds are typically wedge-shaped, and show a primary dip with respect to depositional surface (figure 16). The sandstone beds are dominantly ripple laminated and show sparse escape traces.

\subsubsection{Interpretation}

The coarse grain size of the thicker sandstone bodies at places with concave-upward erosional lower bounding surfaces, dominance of large unidirectional cross-strata particularly in the lower part of the bodies, their fining- and thinning-upward succession indicate channel-fill origin. We interpret these to represent distributary channels debouching in the lake. Lateral transition of the channel sands into wave-rippled and hummocky stratified sandstone and lack of evidences of emergence in the associated facies indicate that at least some of the channels were subaqueous distributary channels (Elliot 1976a, b). Away from the point where the channels entered the lake, basinal wave and storm processes reworked the fluvial sands and generated combined flow bedforms or wave ripples. Inclined wedge-shaped ripple laminated sandstone (figure 16) underlying at places the thick distributary channel sandstones probably represents levee deposits flanking the distributary channels (Elliot 1976a, b). Primary dip of the wedge-shaped strata in the levee deposits reflects the slope of the channel-overbank interface. Close association with wave-rippled sandstone and lack of evidences of emergence point to their subaqueous nature.

\subsection{Wave/storm-affected delta front facies association (FA4)}

Facies $\mathrm{S}_{2}, \mathrm{~S}_{3}$, Ht and $\mathrm{M}_{3}$ are the main components of the association. It characteristically 

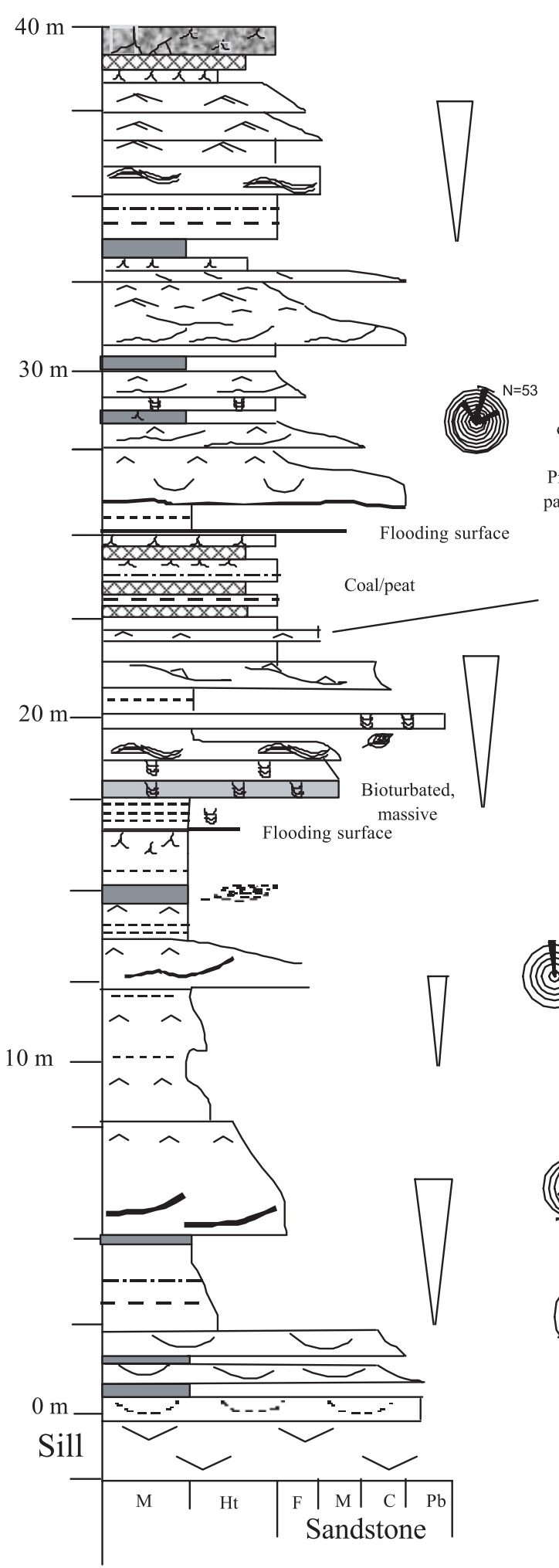
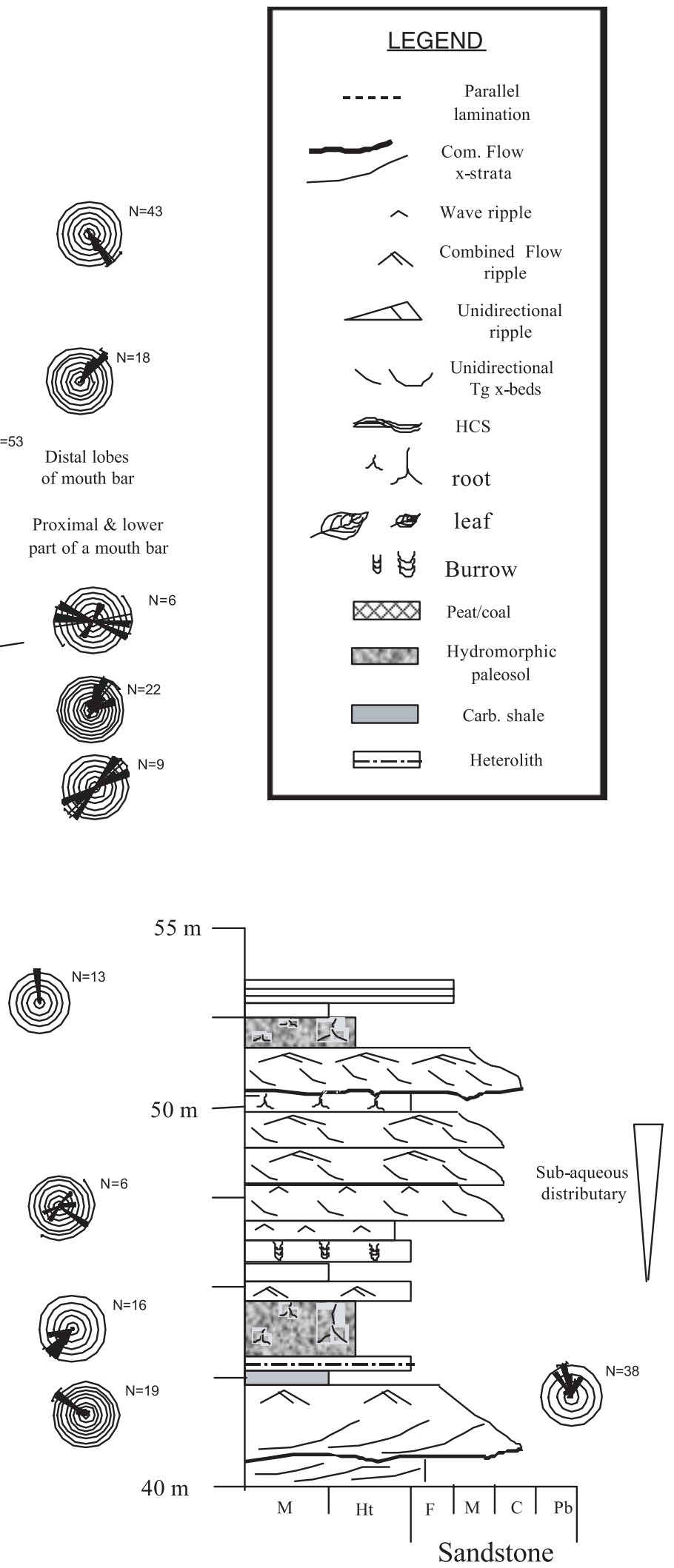

Figure 15. Detailed log of the lacustrine succession of the Bijori Formation; upper part of the Jamru Nala section.

comprises sheet sandstone bodies internally consisting of single or stacked convexo-plan or biconvex sandstone units marked by abundant mudstone-drapes between individual sandstone bodies (figure 17). The sandstone varies from very coarse- to fine-grained and dominant structures 


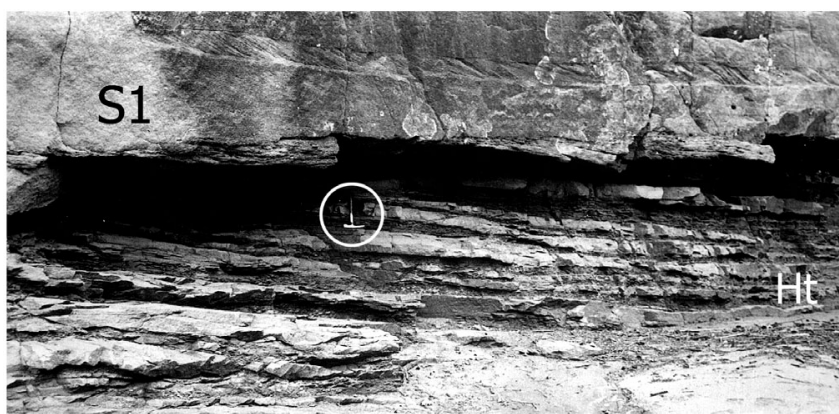

Figure 16. Subaqueous levee deposits (Ht) overlain by thick channel-fill sandstone $\left(S_{1}\right)$ in the Bijori Formation. Note a primary dip of the heterolithic beds with respect to the generalized depositional surface. Note also wedge shape of the individual sandstone sheets in the $\mathrm{Ht}$ facies.

are large combined flow dune cross-stratification and ripple lamination. In one case stacked sets of swaley cross-strata define the main fabric of a FA4 sandstone body. Very coarse sandstone of the facies association shows development of unidirectional trough cross-stratification. The succession of convex-up sandstone bodies in most cases overlies the heterolithic (Ht facies or hydromorphic paleosol horizons $\left(\mathrm{M}_{2}\right)$. At many places the sandstone units show in situ large roots or stems. The convexup sandstone bodies typically thin out in down current and lateral directions and interdigitate with the mudstone-dominated FA5. The central part of the sandstone bodies are usually coarse grained with large unidirectional or combined flow dune stratification, whereas the flanking parts are characterized by wave rippled fine-grained sandstone and heterolithic facies.

\subsubsection{Interpretation}

Smooth, flat lower bounding surfaces of the sandstone bodies indicate their subaqueous emplacement and the feature clearly distinguishes them from channel sandbodies that usually are characterised by a concave-up, irregularly undulating, erosional basal surface. The convex-up tops of these sandstones are attributed to subaqueous wave processes (cf. Gozalo 1985; Brenchley et al 1993; Midtgaard 1996). It is inferred that combined depositional and erosional events related to storm and wave processes shaped the sandstone bodies in a lenticular fashion distinct from that of the fluvial sandstone bodies. The threedimensional geometry of the sandstone bodies with a thicker, coarse-grained central part and finer grained, digitating distal parts dominated by wave ripples represent nearshore shoal or bar bodies (cf. de Raaf et al 1977; Midtgaard 1996). Coarse grain size of the central part of the bar sediments and their rapid lateral grain size variation, common mud-drapes and abundant mudstone-clasts are inferred to indicate a fluvial source and rapid reworking of sediments by wave processes. Angleof-repose foresets characterise the coarsest load, whereas low-angle cross-strata, swaley cross-strata and wave-ripple strata characterise the finer sediments in the fringing parts of the sandstone bodies. Lateral pinching out in all directions accompanied with reduction in grain size, and scale and type of sedimentary structures together with a convexupward geometry are typical of many nearshore bar sandstone bodies (cf. de Raaf et al 1977; Cotter 1985; Midtgaard 1996). Although rare, presence of large roots and stems in these sandstone bodies indicate that the delta front shoal bodies were occasionally exposed and colonised by large plants (cf. Dam and Surlyk 1993; Dam et al 1995).

\subsection{Open lacustrine/lower shoreface facies association (FA5)}

Facies $\mathrm{Ht}$ and $\mathrm{M}_{3}$ are the main components of the association with minor amounts of $\mathrm{S}_{3}$. Individual mudstone-dominated successions usually show a coarsening-upward trend and vary in thickness from less than one metre to about 5 metres (figure 15). Carbonaceous mudstones, the dominant component of this association, are finely laminated (figure 18). Various types and scales of wave ripple lamination (figure 18) and thin units of parallel or hummocky lamination are typical (figure 15). Less common are few centimetres thick intensely burrowed coarse sandstone beds that are interlayered with the carbonaceous shale (figure 14). Irregularshaped, isolated crack-fills occur sporadically in the succession. Leaf impressions are common in many cases but roots or other pedogenic features (e.g., fractures with slickenside and colour mottling) are absent.

\subsubsection{Interpretation}

The facies association represents comparatively deeper part of the Bijori lakes devoid of desiccation features and hydromorphic paleosols. Lack of regular polygonal shape, sporadic nature of occurrence and absence of other emergence features (e.g., roots) are inferred to indicate subaqueous origin of the irregular cracks (synaeresis cracks). However, mud-dominated nature of the association and laminated nature of the $\mathrm{M}_{3}$ indicate that it was deposited in areas off-shore with respect to the shoreface bars and the water depth was probably tens of metres. Abundant presence of wave ripples in this association is inferred to imply that the deepest lake floors of the study area were also within the reach of storm waves. 


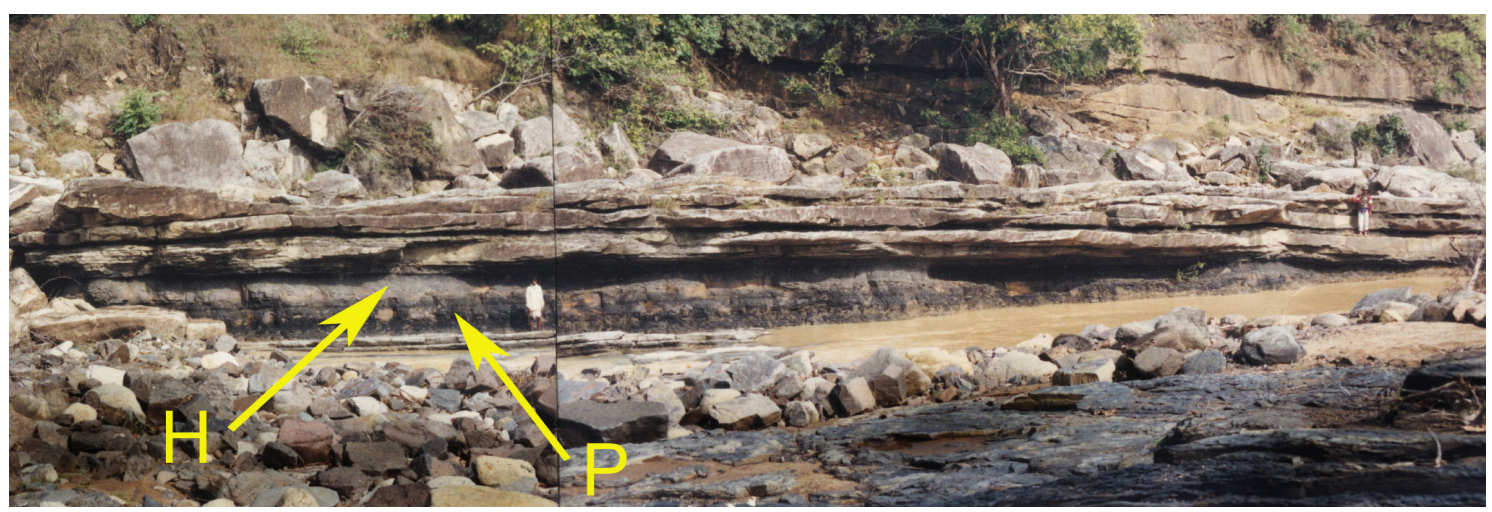

Figure 17. Stacked bi-convex to convexo-planar sandstone bodies representing near shore wave-reworked shoal-bar complexes. The sandstone bodies are separated by thin mudstone. Note that the sandstone bodies overlie a hydromorphic paleosol $(\mathrm{H})$ horizon that in turn overlies a peat $(\mathrm{P})$ horizon. Jamru Nala section, one km SSW of Jamundhonga village.

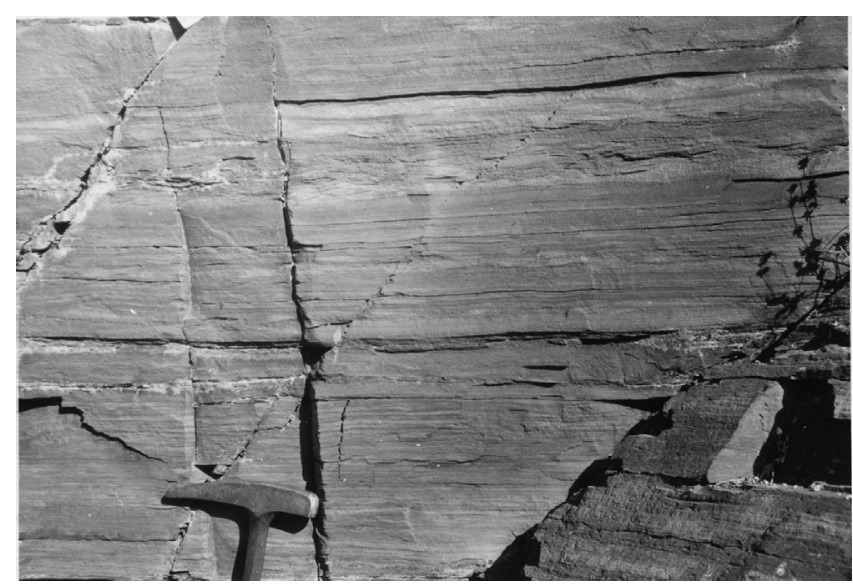

Figure 18. Thin laminations in the carbonaceous mudstone $\left(\mathrm{M}_{3}\right)$ of the open lacustrine deposits. Note increased proportion of fine sandstone upward.

\section{Tectonism and climate}

Geomorphic set up and climates largely control the sediment supply (S) to a non-marine sedimentary system whereas tectonic subsidence and rise in base level controls the accommodation space (A). Therefore, tectonically induced rapid subsidence of a particular region will tend to change its A/S ratio. Flooding of the basin floor is typical of rapid subsidence as water table intersects the surface and spring and river water accumulate forming lakes (Blair and Bilodeau 1988; Olsen et al 1995; Martinsen et al 1999). It is not surprising that most of the large present day lake basins are tectonically formed depressions e.g., East African lake basins - rift basins; Dead sea transform plate margin; Lake Eyre, Australia intracratonic sag basin (cf., Talbot and Allen 1996; Miall 1999). Therefore, existence of the Bijori lake is inferred to represent one of the most active regions of subsidence in the basin. However, marine connections were not established and an inland lake developed probably due its position quite interior of the Tethys margin (Veevers and Tewari 1995).

Climatic change itself can elevate the base level and give rise to local ponding of water in the lowlying areas. However, an extensive lake basin as depicted by the thick succession of Bijori rocks is unlikely to develop unless tectonic subsidence diverts the drainage towards it and deposited sediments are preserved below base level of erosion due to basin floor subsidence. The underlying Motur Formation (see Ray and Chakraborty 2002) and also the lower part of the Bijori Formation (figure 10) contains evidences of a semi-arid climate in the form of calcareous paleosols and redbeds. A major climatic change between Barakar Formation and overlying Motur Formation (table 1) has been documented (Ray and Chakraborty 2002). A similar scale semi-arid to humid climatic oscillation is probably indicated in case of the Motur-Bijori transition. Calcrete-redbed continental successions of Motur Formation are typical of hot, semi-arid climate reflecting higher evaporation over precipitation and a strongly seasonal rainfall pattern. Development of carbonaceous shale, hydromorphic paleosol and thin coal layers in Bijori Formation indicate moist conditions with higher rainfall spread more evenly through the year (Goudie 1983; Boardman 1989; Tandon and Gibling 1994). With active tectonic subsidence and A/S ratio $>1$ (cf., Martinsen et al 1999) lakes can also form in arid to semi-arid climate (e.g., Lake Eyre, Australia; Saline lake basins of California and ancient evaporatic lake deposits of Green River Formation, United States). However, these arid region lakes are characterized by evaporite minerals (e.g., Hardie et al 1978). Absence of evaporite minerals in the Bijori Formation and the characteristic presence of black carbonaceous shales, hydromorpic 
paleosols and coals indicate that during the Bijori period climate again became humid where precipitation was generally high and spread evenly over the year. As a result much larger part of the depositional area remained waterlogged for most of the year favouring preservation of plant organic matter.

\section{Conclusions}

1. Lower part of the Bijori Formation is characterized by stacked braided fluvial sandstone bodies separated by red mudstone and caliche deposits.

2. The present study demonstrates that the middle and upper part of the Bijori Formation represent deposition in shallow lacustrine and lake delta setting refuting the earlier meanderingfluvial interpretation (Tewari 1996). This interpretation is based on abundant wave-, storm- and combined flow-generated structures, evidence of frequent local (seasonal?) water level change and absence of marine signature (e.g., marine fossils or evidence of tides).

3. Facies associations that characterize the lake succession comprise lake shoreline, distributary channel, wave- and storm-affected delta front, and open lacustrine facies association.

4. Existence of the extensive lacustrine sediments demonstrates a period of enhanced tectonic subsidence of the Satpura Gondwana basin during the Late Permian. Preservation of abundant plant remains, presence of thin coal bands and hydromorphic paleosol profiles on the other hand indicate that the semi-arid climate during the deposition of the underlying Motur Formation changed to a wetter climate during the Bijori time.

\section{Acknowledgements}

Late Professor Sukomol Kumar Chanda introduced both of us to the science of sedimentology when we worked under him during earlier parts of our career. His philosophy still dominates our vision of the subject and we fondly cherish memories of many enlightening and intense exchanges with him both in the field and in the laboratory. We are thankful to the editors for inviting us to contribute to this special volume brought out in his memory. We thank many of our colleagues in the Institute, particularly P Ghosh for assistance and interaction during the fieldwork. Comments from the journal reviewers Finn Surlyk, Mangano Buatois and careful scrutiny from the Guest Editors helped to improve the quality of the manuscript. Field and infrastructural facilities were provided by ISI. Financial assistance received from the Department of Science and Technology, New Delhi (ESS/23/VES/072/99) to the first author is also gratefully acknowledged.

\section{References}

Arnott R W C and Southard J B 1990 Exploratory flowduct experiments on combined-flow bed configurations, and some implications for interpreting storm-event stratification; J. Sediment. Pertol. 60 211-219.

Bandyopadhyay S 1999 Gondwana vertebrate faunas of India; Proc. Indian National Science Academy 65A 285-313.

Bandyopadhyay S and Sengupta D P 1999 Middle Triassic vertebrates of India; J. Afr. Earth Scs. 29 233-241.

Besley B and Fielding C R 1989 Palaeosols in Westphalian coal-bearing and red-bed sequences, Central and Northern England: Palaeogeogr. Palaeoclimatol. Palaeoecol. 70 303-330.

Blair T C and Bilodeau W L 1988 Development of tectonic cyclothems in rift, pull-apart, and foreland basins: Sedimentary response to episodic tectonism; Geology $\mathbf{1 6}$ 517-520.

Bluck B J 1974 Structures and directional properties of some valley sandur deposits in southern Iceland; Sedimentology 21 533-554.

Boardman E L 1989 Coal measures (Namurian and Westphalian) Blackband iron formations: fossil bog iron ores; Sedimentology 36 621-633.

Brenchley P J, Pickerill R K and Stromberg J 1993 The role of wave reworking on the architecture of storm sandstone facies, Bell Island Group (Lower Ordovician), eastern Newfoundland; Sedimentology 40 359-382.

Brettle M J, Mcilroy D, Elliot T, Davies S J and Waters C N 2002 Identifying cryptic tidal influences within deltaic successions: an example from the Marsdenian (Namurian) interval of the Pennie Basin, UK; J. Geol. Soc. London 159 379-391.

Buatois L A and Mangano M G 1995a Post glacial lacustrine event sedimentation in an ancient mountain setting: Carboniferous Lake Malanzan (Western Argentina); J. Paleolimnol. 12 1-22.

Buatois L A and Mangano M G 1995b Sedimentary dynamics and evolutionary history of a late Carboniferous Gondwanic lake in northwestern Argentina; Sedimentology 42 415-436.

Buillit N, Lallier-Vergés E, Pradier B and Nicolas G 2002 Coal petrographic genetic units in deltaic-plain deposits of the Campanian Mesaverde Group (New Mexico, USA); Int. J. Coal Geol. 51 93-110.

Casshyap S M 1979 Patterns of sedimentation in Gondwana basins; In: IV International Gondwana Symposium (eds) B Laskar and C S Raja Rao (Delhi: Hindusthan Publishing Corporation), Pp. 525-551.

Casshyap S M and Qidwai H A 1971 Palaeocurrent analysis of Lower Gondwana sedimentary rocks, Pench valley coalfield, Madhya Pradesh (India); Sediment. Geol. 5 $135-145$.

Chakraborty T, Chakraborty C and Ghosh P 2000 Recognition and analysis of fluvial deposits: a brief overview; Indian J. Geol. 72 77-106.

Collinson J D 1996 Alluvial Sediments. In: Sedimentary Environments: Processes, Facies and Stratigraphy; 3rd edn (ed.) H G Reading: (Oxford: Blackwell Science), Pp. 37-81. 
Collinson J D and Thompson D B 1989 Sedimentary Structures, 2nd edn (London: Unwyn Hyman) p. 260.

Cotter E 1985 Gravel-topped offshore bar sequences in the Lower Carboniferous of southern Ireland; Sedimentology 32 195-213.

Crookshank H 1936 The geology of the northern slopes of the Satpuras between the Morand and Sher rivers; Mem. Geol. Surv. India 66(2) 218.

Dam G and Surlyk F 1993 Cyclic sedimentation in a large wave- and storm-domianted anoxic lake; Kap Stewart Formation (Rhaetian-Sinemurian), Jameson Land, East Greenland; In: Sequence Stratigraphy and Facies Associations (eds) B H W Posamentier, C P Summerhays, B U Haq and G P Allen, Int. Assoc. Sedimentologists Spec. Publ. 18 419-448.

Dam G, Surlyk F, Mathiesen A and Christiansen F G 1995 Exploration significance of lacustrine forced regression of Rhaetian-Sinemurian Kap Stewart Formation, Jameson land, East Greenland; In: Sequence Stratigraphy on the northwest European Margin (eds) R J Steel et al: Norwegian Petroleum Society Special Publication $\mathbf{5}$ 511-527.

Datta B, Sarkar S and Chaudhuri A K 1999 Swaley cross-stratification in medium to coarse sandstone produced by oscillatory and combined flows: examples from the Proterozoic Kansapathar Formation, Chhattisgarh Basin, M.P., India; Sediment. Geol. 129 51-70.

de Raaf J F M, Boersma J R and Van Gelder A 1977 Wave generated structures and sequences from a shallow marine succession, Lower Carboniferous, County Cork, Ireland; Sedimentology 4 1-52.

Duchaufour P 1982 Pedology (London: Allen \& Unwin) p. 448.

Duke W L 1985 Hummocky cross-stratification, tropical hurricanes, and intense winter storms; Sedimentology $\mathbf{3 2}$ 167-194.

Dutt A B and Mukhopadhyay S K 2001 Recent advances in knowledge of near-shore signatures within fluvial lower Gondwana (early Permian) sequences in parts of Satpura basin, central India; Proc. National Seminar on Recent Advances in Geology of Coal and Lignite Basins of India. Geol. Surv. India, Spec. Publ. 54 69-86.

Elliot T 1976a Upper Carboniferous sedimentary cycles produced by river-dominated, elongate deltas; J. Geol. Soc. London 132 199-208.

Elliot T 1976b The morphology, magnitude and regime of a Carboniferous fluvial-distributary channel; J. Sediment. Petrol. 46 70-76.

Eyles N and Clark B M 1986 Significance of hummocky and swaley cross-stratification in late Pleistocene lacustrine sediments of the Ontario Basin, Canada; Geology 14 679-682.

Eyles N and Clark B M 1988 Storm influenced deltas and ice scouring in a late Pleistocene glacial lake; Geol. Soc. America Bull. 100 793-809.

Goudie A S 1983 Calcrete; In: Chemical Sediments and Geomorphology, (eds) A S Goudie and K Pye (London: Academic Press) Pp. 93-131.

Gozalo M C 1985 Sedimentary lobes in a tidally influenced alluvial area, Capella Formation, Temp-Graus Basin, Southern Pyrenees, Spain; Geol. Mijn. 64 145-157.

Greenwood B and Sherman D 1986 Hummocky crossstratification in the surf zone: flow parameters and bedding genesis; Sedimentology 33 33-45.

Gupta A 1999 Early Permian palaeoenvironment in Damodar valley coalfields, India: an overview; Gond. Res. 2 149-165.
Gupta A 2000 Role of storm in Ramgarh and West Bokaro coalfields and its implication in adjacent peninsular Gondwana coalfields, India; Gond. Res. 3 529-544.

Hamblin A P 1992 Half-graben lacustrine sedimentary rocks of the lower Carboniferous Strathlorne Formation, Horton Group, Cape Breton Island, Nova Scotia, Canada; Sedimentology 39 263-284.

Hardie L A, Smoot J P and Eugester H P 1978 Saline lakes and their deposits: a sedimentological approach, In: Modern and Ancient Lake Sediments (eds) A Matter and M E Tucker, Int. Assoc. Sedimentologists Spec. Publ. 2 $7-41$.

Harms J C 1969 Hydraulic significance of some sand ripples; Geol. Soc. America Bull. 80 363-396.

Harms J C, Southard J B and Walker R G 1982 Structures and Sequences in Clastic Rocks; Lecture Notes, Soc. Econ. Palaeontol. and Mineral. Short Course 9, Calgary.

Lydekker R 1885 Maleri and Denwa reptiles and amphibians; Pal. Indica (Sr. 4) 1(5) 1-38.

Martinsen O J, Ryseth A, Helland-Hansen W, Flesche H, Torkildsen G and Idil S 1999 Stratigraphic base-level and fluvial architecture: Ericson Sandstone (Campanian), Rock Springs Uplift, SW Wyoming, USA; Sedimentology $46235-259$.

Maulik P K, Chakraborty C, Ghosh P and Rudra D 2000 Meso- and macro-scale architecture of a Triassic fluvial succession: Denwa Formation, Satpura Gondwana Basin, Madhya Pradesh; J. Geol. Soc. India 56 489-504.

Miall A D 1999 Principles of Sedimentary Basin Analysis; 3rd edn (New York: Springer-Verlag) p. 700.

Midtgaard H H 1996 Inner-shelf to lower-shoreface hummocky sandstone bodies with evidence for geostrophic influenced combined flow, lower Cretaceous West Greenland; J. Sediment. Res. 66 343-353.

Myrow P M and Southard J B 1991 Combined-flow model for vertical stratification sequences in shallow marine storm-deposited beds; J. Sediment. Petrol. 61 202-210.

Nemec W 1992 Depositional controls on plant growth and peat accumulation in a braidplain delta environment: Helvetiafjellet Formation (Barremian-Aptian), Svalbard; In: Controls on the distribution and quality of Cretaceous coals; (eds) P J McCabe and J T Parrish, Spec. Pap. Geol. Soc. America 267 209-226.

Nottvedt A and Kreisa R D 1987 Model for combinedflow origin of hummocky cross-stratification; Geology 15 $357-361$.

Olsen T, Steel R, Hosgeth K, Skar T and Roe S L 1995 Sequential architecture in a fluvial succession: sequence stratigraphy in the upper Cretaceous Mesaverde Group, Prince canyon, Utah; J. Sedment. Res. B 65 265-280.

Pascoe E H 1959 A manual of the geology of India and Burma; 3rd edn (Calcutta: Govt. of India Press) p. 2130.

Plummer P S and Gostin V A 1981 Shrinkage cracks: desiccation or synaeresis? J. Sediment. Petrol. 51 1147-1156.

Raja Rao C S 1983 Coalfields of India. Vol-III, Coal resources of Madhya Pradesh and Jammu \& Kashmir. Bull. Geol. Surv. India, Series A 45204.

Retallack G J 1997 A colour guide to paleosols (Chichester: John Wiley \& Sons) p. 175.

Ray S and Chakraborty T 2002 Lower Gondwana fluvial succession of the Pench-Kanhan valley, India: stratigraphic architecture and depositional controls; Sediment. Geol. 151 243-271.

Schoch R and Milner A 2000 Encyclopedia of Paleoherpetology, Part 3B, Stereospondyli (Munchen: Verlag Dr. Friedrich Pfeil) p. 203.

Smith R M H 1993 Vertebrate taphonomy of Late Permian floodplain deposits in the southwestern Karoo Basin of South Africa; Palaios 8 45-67. 
Southard J B, Lambie J M, Frederico D C, Pile H T and Weidman C R 1990 Experiments on bed configurations in fine sands under bidirectional purely oscillatory flow, and the origin of hummocky cross-stratification; J. Sediment. Petrol. 60 1-17.

Surlyk F and Noe-Nygaard N 1986 Hummocky crossstratification from the Lower Jurassic Hasle Fornation of Bornholm, Denmark; Sediment. Geol. 46 259-273.

Tandon S K, Gibling M R 1994 Calcrete and coal in late Carboniferous cyclothems of Nova Scotia, Canada: climate and sea-level changes linked; Geology 22 $755-758$.

Talbot M R and Allen P A 1996 Lakes. In: Sedimentary Environments: Processes, Facies and Stratigraphy 3rd edn (ed.) H G Reading (Oxford: Blackwell Science) Pp. 83-124.
Tewari R C 1996 Tectono-sedimentary evolution of Bijori (Late Permian) and Pachmarhi (Early Triassic) Formations of Satpura Gondwana Basin, central India; Ind. J. Petroleum Geol. 4 75-86.

Van de Meene J W H, Boersma J R and Terwindt J H J 1996 Sedimentary structures of combined flow deposits from the shoreface-connected ridges along the central Dutch coast; Mar. Geol. 131 151-175.

Veevers J J and Tewari R C 1995 Gondwana master basin of peninsular India between Tethys and the interior of Gondwanaland Province of Pangea; Geol. Soc. America Mem. 187 p. 72.

Werneburg R and Schneider J 1996 The Permian temnospondyle amphibians of India; In: Studies on Carboniferous and Permian vertebrates (ed.) A R Milner, Spec. Pap. Palaeont. 52 105-128. 